\title{
Review \\ Human NK Cells in Autologous Hematopoietic Stem Cell Transplantation for Cancer Treatment
}

\author{
Ane Orrantia ${ }^{1}$, Iñigo Terrén ${ }^{1}\left[\right.$, Gabirel Astarloa-Pando ${ }^{1}$, Olatz Zenarruzabeitia ${ }^{1, *(\mathbb{D})}$ \\ and Francisco Borrego 1,2,*(D) \\ 1 Immunopathology Group, Biocruces Bizkaia Health Research Institute, 48903 Barakaldo, Spain; \\ ane.orrantiarobles@osakidetza.eus (A.O.); inigo.terrenmartinez@osakidetza.eus (I.T.); \\ gabirel.astarloapando@osakidetza.eus (G.A.-P.) \\ 2 Ikerbasque, Basque Foundation for Science, 48013 Bilbao, Spain \\ * Correspondence: olatz.zenarruzabeitiabelaustegui@osakidetza.eus (O.Z.); \\ francisco.borregorabasco@osakidetza.eus (F.B.); Tel.: +34-94-600-6000 (ext. 2402) (O.Z.); \\ +34-94-600-6000 (ext. 7079) (F.B.)
}

Citation: Orrantia, A.; Terrén, I.; Astarloa-Pando, G.; Zenarruzabeitia, O.; Borrego, F. Human NK Cells in Autologous Hematopoietic Stem Cell Transplantation for Cancer Treatment. Cancers 2021, 13, 1589. https:// doi.org/10.3390/cancers13071589

Academic Editors: Paola Vacca and Laura Chiossone

Received: 26 February 2021

Accepted: 26 March 2021

Published: 30 March 2021

Publisher's Note: MDPI stays neutral with regard to jurisdictional claims in published maps and institutional affiliations.

Copyright: (c) 2021 by the authors. Licensee MDPI, Basel, Switzerland. This article is an open access article distributed under the terms and conditions of the Creative Commons Attribution (CC BY) license (https:/ / creativecommons.org/licenses/by/ $4.0 /)$.
Simple Summary: Natural killer (NK) cells are key elements of the innate immune system that have the ability to kill transformed (tumor and virus-infected) cells without prior sensitization. Hematopoietic stem cell transplantation (HSCT) is a medical procedure used in the treatment of a variety of cancers. The early reconstitution of NK cells after HSCT and their functions support the therapeutic potential of these cells in allogenic HSCT. However, the role of NK cells in autologous HSCT is less clear. In this review, we have summarized general aspects of NK cell biology. In addition, we have also reviewed factors that affect autologous HSCT outcome, with particular attention to the role played by NK cells.

Abstract: Natural killer (NK) cells are phenotypically and functionally diverse lymphocytes with the ability to recognize and kill malignant cells without prior sensitization, and therefore, they have a relevant role in tumor immunosurveillance. NK cells constitute the main lymphocyte subset in peripheral blood in the first week after hematopoietic stem cell transplantation (HSCT). Although the role that NK cells play in allogenic HSCT settings has been documented for years, their significance and beneficial effects associated with the outcome after autologous HSCT are less recognized. In this review, we have summarized fundamental aspects of NK cell biology, such as, NK cell subset diversity, their effector functions, and differentiation. Moreover, we have reviewed the factors that affect autologous HSCT outcome, with particular attention to the role played by NK cells and their receptor repertoire in this regard.

Keywords: NK cells; hematopoietic stem cell transplantation (HSCT); autologous HSCT; graft versus tumor; graft versus leukemia; KIR; HLA; multiple myeloma; non-Hodgkin lymphoma

\section{Introduction}

Natural killer (NK) cells constitute an essential part of the innate immune system and probably are the best-known members of the heterogeneous family of the innate lymphoid cells (ILCs). In contrast to T and B lymphocytes, ILCs lack rearranged antigen-specific receptors and act early in the immune response [1]. ILCs are classified into five different subsets based on their transcriptional profile and functions: ILC1, ILC2, ILC3, lymphoid tissue-inducer (LTi) cells, and NK cells [2]. Moreover, ILCs can be grouped into cytotoxic ILCs and non-cytotoxic "helper" ILCs. NK cells represent the classic cytotoxic population of ILCs [3,4]. As ILC1s, NK cells also produce the pro-inflammatory cytokine interferon (IFN)- $\gamma$ but are dependent on both T-bet and eomesodermin (Eomes) transcription factors to develop, while ILC1s only depend on T-bet [5,6]. Even if generally classified into the abovementioned five subsets, several studies have also demonstrated that ILCs can 
transdifferentiate into other ILC subsets depending on the cytokine milieu, evidencing the plasticity and the heterogeneity of these cells [7-10].

Upon activation, NK cells can mediate different effector mechanisms to eliminate both normal and transformed (tumor and virus-infected) cells [11]. NK cell activation may trigger the release of cytolytic granules to the immunological synapse leading to the killing of target cells. These granules are composed of perforin and granzymes. Perforin is a pore-forming molecule that facilitates granzymes to enter into the target cells [12]. Then granzymes initiate target cell apoptosis by different pathways. For instance, granzyme B can cleave pro-caspases into active caspases inducing caspase-dependent cell death or can activate mitochondrial death pathway [11,13]. In addition to the perforin/granzyme pathway, NK cells also express FasL and TRAIL, which are ligands for tumor-cells expressing Fas (CD95) and TRAIL receptors, members of the tumor necrosis factor (TNF) receptor superfamily. The engagement of these death receptors with their corresponding ligands also contributes to NK cell cytotoxicity by activating the caspase enzymatic cascade that causes the apoptosis of the target cell $[11,14,15]$. Moreover, the anti-tumor and anti-viral activity of NK cells also involves the secretion of cytokines, as, e.g., IFN- $\gamma$, which act on tumor and virus-infected cells [16]. Finally, NK cells through their cytotoxic activity and secretion of cytokines and chemokines also have a very important role in shaping the innate and adaptive immune responses [17].

Many studies performed in mice support the notion that NK cells play a critical role in the eradication of tumor cells [18-20]. In humans, in an 11-year follow-up study, it was found that low natural cytotoxic activity of peripheral-blood mononuclear cells was associated with increased cancer risk [21]. Moreover, in acute myeloid leukemia (AML) patients receiving alloreactive NK cells in the course of allogenic hematopoietic stem cell transplantation (alloHSCT), a reduced incidence of relapse was observed in patients who lacked the human leukocyte antigen (HLA) ligands for donor inhibitory killer cell immunoglobulin-like receptors (KIRs) [22]. Thus, these data indicate a significant role for NK cells in tumor surveillance.

\section{NK Cell Subset Diversity}

Traditionally, according to the differential expression of CD56 and CD16, human NK cells are divided in two major subsets known as CD56 bright CD $16^{\text {low } /-}$ and CD56 ${ }^{\mathrm{dim}} \mathrm{CD} 16^{+}$ (hereafter referred to as CD56 ${ }^{\text {bright }}$ and CD56 ${ }^{\mathrm{dim}}$, respectively) [23]. Although both subsets express similar levels of several surface receptors such as the common interleukin (IL)-2 and IL-15 receptor beta chain (IL-2/15R $\beta)$, NKG2D, and NKp80, there are some distinct phenotypical and functional features between them [24]. For instance, CD56 ${ }^{\text {bright }} \mathrm{NK}$ cells express CD94/NKG2A (hereafter NKG2A) but lack the expression of KIRs. They also show low expression of perforin and granzymes A and B and low or undetectable expression of CD16. In addition, they produce large amounts of immunomodulatory cytokines and chemokines in response to cytokines but are poor mediators of direct cytotoxicity and antibody-dependent cell-mediated cytotoxicity (ADCC) $[23,25,26]$. However, it has been also demonstrated that after cytokine activation they become more cytotoxic, as, e.g., upon priming with IL-15 and after expansion with K562-mb-IL21 feeder cells, the CD56 superbright $^{\mathrm{C}} \mathrm{D} 16^{+} \mathrm{NK}$ cells exhibit increased degranulation after target recognition $[27,28]$. Conversely, CD56 ${ }^{\mathrm{dim}} \mathrm{NK}$ cells are characterized by lower expression of NKG2A and high expression of CD16, perforin, granzymes, and KIRs. Moreover, CD56 ${ }^{\mathrm{dim}}$ NK cells are highly cytotoxic but produce lower amounts of cytokines in response to monocyte-derived cytokines [23,25]. Nevertheless, they can produce significant amounts of cytokines upon target cell recognition [29,30]. CD56 ${ }^{\text {dim }}$ NK cells that lack CD16 expression have also been identified in patients undergoing haploidentical HSCT. Due to their transcriptional profile, these cells, also known as unconventional CD56 ${ }^{\mathrm{dim}} \mathrm{NK}$ cells, are considered to be an intermediate stage between CD56 $6^{\text {bright }}$ and CD56 ${ }^{\mathrm{dim}} \mathrm{NK}$ cells [31]. Finally, CD56 ${ }^{\text {bright }}$ and CD56 $6^{\mathrm{dim}} \mathrm{NK}$ cells also exhibit different expression patterns of chemokine and homing receptors, which are linked to 
their tissue localization [32]. CD56 bright are the predominant NK cell subsets in secondary lymphoid tissues (SLT), while CD56 ${ }^{\mathrm{dim}}$ are the main subset in the peripheral blood $[23,25]$.

However, results published over the last years have revealed that human NK cells are much more diverse than just CD56 $6^{\text {bright }}$ and CD56 ${ }^{\text {dim }}$ subsets. A study using mass cytometry that simultaneously analyzed more than 30 parameters revealed that, within an individual, there may be 6000-30,000 phenotypically distinct peripheral blood NK cells, highlighting the existing NK cell diversity [33]. Furthermore, recently, the diversity of peripheral blood NK cells has also been revealed by single-cell RNA sequencing analysis [34]. This phenotypic diversity is mainly influenced by genetics and environmental factors. Genetics strongly influence the combinatorial expression patterns of KIRs that recognized HLA class I molecules. Moreover, different environmental factors influence the expression of activating and costimulatory receptors [33,35]. For example, HLA-DR expression varies in response to activation [36,37], the expression of CD117 differs during differentiation [38] and the expression of 2B4 could be regulated in response to viral infection [39]. Furthermore, different tissue-resident NK cell subpopulations have been identified in different peripheral tissues, such as human liver, uterus, spleen, intestine, and salivary gland, showing that local tissue environment also contributes to NK cell diversity [35,40]. These tissue-resident NK cells are in general CD56 ${ }^{\text {bright }}$, express tissue-residency markers (e.g., CD49a, CD69, and CD103), which are involved in retaining lymphocytes in tissues, and present unique transcriptional signatures distinct from peripheral blood NK cells [25,41].

Infections by different pathogens also contribute to NK cell diversity. For instance, infection with human cytomegalovirus (CMV), a DNA virus that belongs to the herpesvirus family, is associated with important changes in the configuration of the NK cell repertoire [42]. Increased numbers of CD94/NKG2C+ (hereafter NKG2C+) NK cells, commonly known as adaptive NK cells, have been observed following CMV infection or reactivation in different clinical settings [43-45]. These adaptive NK cells exhibit memory properties such as increased CD16-triggered responses [46]. CMV infection is also associated with an increase in CD57 expression on NK cells [47]. Although NKG2C+ NK cells expansion has been observed in patients infected by other viruses, it only occurs in individuals who have been previously infected with $\mathrm{CMV}$, thus suggesting that the expansion of these cells might be specific to human CMV [42,46]. On the other hand, adaptive NK cells subsets are also characterized by the lack of expression of $\mathrm{FcE}_{\mathrm{R}} \gamma$, and they also exhibit an enhanced ADCC. These FceR $\gamma$-negative adaptive NK cells have been described to be expanded in CMV infection, although they can be found in CMV seronegative individuals as well [46,48]. Furthermore, even though the lack of FceR $\gamma$ is often associated with NKG2C expression, both markers appear occasionally disassociated, suggesting the existence of distinct human adaptive NK cell subsets [49].

Additionally, other viral infections (e.g., human immunodeficiency virus (HIV)-1) and also aging, alter NK cell subsets repertoire. An expansion of CD56 ${ }^{\text {neg }} \mathrm{CD} 16^{+} \mathrm{NK}$ cell subset (hereafter CD56 ${ }^{\text {neg }}$ ) has been described in both situations $[47,50,51]$. CD56 ${ }^{\text {neg }}$ NK cells are very scarce in the peripheral blood of healthy individuals and their expansion occurs primarily at the expenses of CD56 ${ }^{\mathrm{dim}} \mathrm{NK}$ cells [52]. Proteome analysis of CD56 ${ }^{\text {neg }} \mathrm{NK}$ cells from healthy individuals revealed that this subset has an overall CD56 ${ }^{\mathrm{dim}}$-like phenotype [53]. Moreover, they have been classically described as dysfunctional, even though some studies suggest that the effector functions of CD56 $6^{\text {neg }} \mathrm{NK}$ cells, although lower compared to CD56 dim NK cells, are not as diminished as previously thought [54-56]. The differences among studies may be due to an inadequate identification of this cell subset $[55,57]$. More age-related alterations have also been described such as a reduced frequency of CD56 $6^{\text {bright }} \mathrm{NK}$ cells in elderly individuals and decreased expression of receptors such as NKp30, NKp46, and DNAM-1 on CD56 $6^{\text {dim }}$ NK cells. Furthermore, aging affects NK cell cytotoxicity against classic NK cell targets while ADCC is maintained [58]. Lastly, compared to children, adults show lower developmental marker diversity on NK cells [59].

The necessity to clarify and better understand the NK cell heterogeneity is very evident when novel NK cell subsets that have an impact on the prognosis of different pathological 
settings are identified. For instance, Stannard et al. identified a new terminally differentiated CD $56^{\text {dim }}$ NK cell subset that lack expression of DNAM-1 and, among others, present low production of IFN $\gamma$ and limited killing capacities. These authors reported a decline in the ratio of CD56 ${ }^{\text {dim }}$ DNAM- $1^{+} /$CD56 $6^{\text {dim }}$ DNAM- $1^{\text {neg }}$ NK cell subsets and a reduced cytotoxicity of CD56 ${ }^{\text {dim }}$ DNAM-1 ${ }^{+}$NK cells in the blood of patients with Hodgkin lymphoma and diffuse large-B cell lymphoma that may have clinical implications [60]. Moreover, recently, a new subset of cord blood-derived NK cells with an immature phenotype, poor effector functions and low diversity index was associated with relapse after cord blood transplantation [61].

\section{Human NK Cell Receptors and Effector Functions}

The capacity to recognize and spontaneously eliminate virus-infected and tumor cells is one of the key functions of NK cells. This function is tightly regulated by a wide range of receptors expressed at the cell surface of NK cells [62]. One type of receptors expressed on the surface of NK cells are inhibitory receptors, which can be divided in two main groups. The first group comprise KIRs, which signal upon binding to classical major histocompatibility complex (MHC) class I molecules HLA-A, -B, and -C (Table 1) [63]. The second group comprise the C-type lectin-like heterodimeric receptor NKG2A (and its isoform NKG2B) which recognize the non-classical MHC class I molecule HLA-E [64]. Via inhibitory receptors, NK cells are able to detect the absence of self-molecules, specifically destroying cells that have downregulated HLA class I molecules, a frequent event in cancer cells (Figure 1). This is known as the missing-self recognition [65]. Moreover, NK cells may exert anti-tumor effect due to KIR-HLA class I mismatch. As demonstrated in AML patients undergoing HLA-mismatched alloHSCT, HLA class I-binding receptors of donor NK cells do not engage with their cognate ligand on recipient cells and thus, sense the missing expression of self-HLA class I molecules [66-68]. In this scenario, the inhibitory signal mediated by inhibitory receptors upon engagement with their ligands will be absent, thus allowing the killing of the target cells by donor NK cells. Also, and to avoid NK cell activation against self-healthy cells, during development, NK cells must randomly express at least one inhibitory receptor matching the own MHC class I molecules. Otherwise, NK cells become somehow anergic in a process known as NK cell "education" or "licensing" [69]. NK cells can also express other additional constitutive or inducible inhibitory receptors that serve as immune checkpoints for cell activation, (e.g., PD-1, TIGIT, CD96, CD300a, etc.). Upon interaction with their ligands, these receptors hamper NK cell IFN- $\gamma$ production and NK cell-mediated cytotoxicity $[70,71]$.

However, there are some situations that cannot be explained by the abovementioned missing-self hypothesis. For example, self-cells lacking MHC class I expression, such as human erythrocytes, are not eliminated by NK cells. Moreover, under some circumstances, NK cells are able to eliminate MHC class I-expressing tumor cells. This is because NK cells also have the capability to detect stress-induced ligands present on transformed cells, leading to the postulation of the "induced-self" model [72]. The recognition of those inducible ligands is mediated by a broad spectrum of activating receptors present on the surface of NK cells. Natural cytotoxicity receptors (NCR) are one of the family of activating receptors. These NCRs include NKp46, NKp30, and NKp44, being the last one only expressed after activation of NK cells, while NKp46 and NKp30 are constitutively expressed [73]. Ligands for this family of receptors have been detected not only on many tumor cells but also in some healthy tissues [74]. Other well-studied and particularly important activating receptor is the C-type lectin-like activating receptor NKG2D, which is expressed as a homodimer in virtually all NK cells. In humans, two families of NKG2D ligands (NKG2DLs) have been described: the MHC class I chain-related molecules A and $\mathrm{B}$ (MICA and MICB) and the UL16-binding proteins (ULBP). NKG2DLs are, in general, not considered to be expressed on healthy tissues, instead their expression is induced by cellular stress [75]. Other activating receptors expressed by NK cells are the heterodimeric receptor CD94/NKG2C, that interacts with HLA-E and DNAM-1, which compete with 
TIGIT and CD96 for binding to its ligands PVR (CD155) and Nectin-2 (CD112). Moreover, the function of these activating receptors can be enhanced by a second family of activating co-receptors (e.g., 2B4 and NKp80) whose action requires the co-engagement of the main activating receptors [70].

Table 1. Inhibitory and activating killer cell immunoglobulin-like receptors (KIRs) and their human leukocyte antigen (HLA) class I ligands.

\begin{tabular}{|c|c|}
\hline Inhibitory KIRs & Ligands \\
\hline KIR2DL1 & HLA-C C2 \\
\hline KIR2DL2 & $\begin{array}{l}\text { HLA-C C1 } \\
\text { HLA-B* }{ }^{*} 46: 01 \\
\text { HLA-B*73:01 }\end{array}$ \\
\hline KIR2DL3 & $\begin{array}{l}\text { HLA-C C1 } \\
\text { HLA-B*46:01 } \\
\text { HLA-B*73:01 }\end{array}$ \\
\hline KIR2DL4 & HLA-G \\
\hline KIR2DL5 & Unknown \\
\hline KIR3DL1 & $\begin{array}{c}\text { HLA-B Bw4 } \\
\text { HLA-A*23 } \\
\text { HLA-A*24 } \\
\text { HLA-A*32 }\end{array}$ \\
\hline KIR3DL2 & $\begin{array}{c}\text { HLA-A*03 } \\
\text { HLA-A*11 } \\
\text { HLA-F }\end{array}$ \\
\hline KIR3DL3 & Unknown \\
\hline Activating KIRs & Ligands \\
\hline KIR2DS1 & HLA-C C2 \\
\hline KIR2DS2 & $\begin{array}{c}\text { HLA-C C1 } \\
\text { HLA-A*11:01 }\end{array}$ \\
\hline KIR2DS3 & Unknown \\
\hline KIR2DS4 & $\begin{array}{l}\text { HLA-C }{ }^{*} 02: 02 \\
\text { HLA-C }{ }^{*} 04: 01 \\
\text { HLA-C }{ }^{*} 05: 01 \\
\text { HLA-C }{ }^{*} 01: 02 \\
\text { HLA-C }{ }^{*} 14: 02 \\
\text { HLA-C }{ }^{*} 16: 01 \\
\text { HLA-A }{ }^{*} 11: 01 \\
\text { HLA-F }\end{array}$ \\
\hline KIR2DS5 & HLA-C C2 \\
\hline KIR3DS1 & $\begin{array}{c}\text { HLA-F } \\
\text { HLA-B*51 }\end{array}$ \\
\hline
\end{tabular}




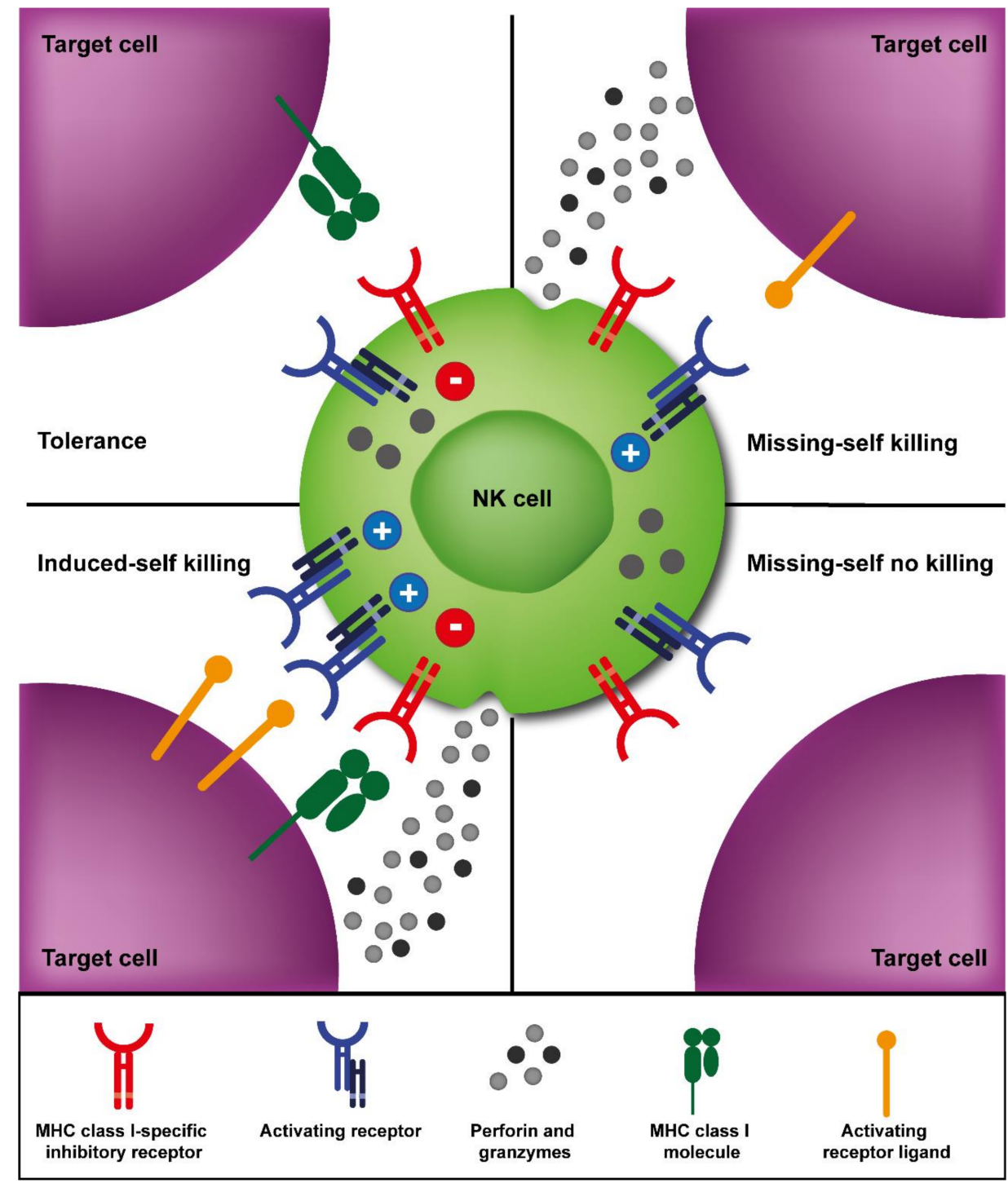

Figure 1. Natural killer (NK) cell activation is determined by an intricate balance between activating and inhibitory signals transmitted by surface receptors. Target cells expressing major histocompatibility complex (MHC) class I molecules that engage MHC class I-specific inhibitory receptors expressed by NK cells will not be killed (tolerance) due to inhibitory signals transmitted by the inhibitory receptors. Target cells that display an upregulation of activating receptor ligands will be killed (induced-self killing) as activating signals will overcome the inhibitory signals. Target cells that downregulate MHC class I molecules will be eliminated depending on the presence of signals transmitted by the activating receptors (missing-self). After activation, NK cells will mediate different effector mechanisms to eliminate target cells, such as the release of cytolytic granules containing perforin and granzymes.

Thus, the intricate balance between activating and inhibitory signals transmitted by the surface receptors determines if NK cells will be activated and, consequently, what will be the outcome of the encounter with the potential target cell. Healthy cells expressing self-MHC class I molecules and none or few activating ligands will not be attacked by NK cells (tolerance), while transformed cells that present a reduced expression or mismatch expression of MHC class I molecules (missing-self) and/or an increased expression of activating ligands (induced-self) will be eliminated (Figure 1) [76]. Moreover, NK cells are also strongly activated via CD16 surface receptor that recognize the Fc portion of IgG antibodies, and thus are able to kill antibody-coated cells via ADCC. Apart from activating and inhibitory receptors, NK cell activation is also regulated by cytokines secreted by 
other cells, via the engagement of cytokine receptors present on the surface of NK cells. Particularly, IL-15 is a critical cytokine for NK cell differentiation [77]. Moreover, IL-2 and IL-15 are needed for NK cell survival and proliferation [78]. Furthermore, cooperative effect of IL-2 and IL-15 and other cytokines such as IL-12 and IL-18 induce high IFN $\gamma$ production by NK cells [79].

\section{NK Development and Differentiation}

The development of NK cells, as it occurs with other leukocytes, comprise a succession of coordinated differentiation steps that lead to commitment toward NK cell lineage and to the acquisition of functional competency. Traditionally, bone marrow has been considered the major site of NK cell generation and differentiation. However, studies carried out over the last years describing the presence of different NK cell progenitors in tissues other than bone marrow evidence that NK cell development also occurs in extra-medullary sites [80]. Thus, it is now well accepted that NK cells can also migrate, develop, and mature in SLT, as is the case of lymphoid nodes [81,82].

Due to obvious experimental limitations, a detailed picture of human NK cell development has been difficult to obtain. Moreover, the classical developmental model in where hematopoietic stem cells (HSCs) bifurcate into common myeloid progenitors (CMP) and common lymphoid progenitor (CLP) was challenged by the discovery of a lymphoid-primed multipotent progenitor (LMPPs) that sustains lymphoid and myeloid potential [83]. The definition of a lineage-restricted NK cell progenitor has been also difficult to achieve given the complexity and plasticity of early hematopoiesis and lineage commitment. Nevertheless, phenotypically distinct progenitors that give rise to NK cells have been described [84-90]. Years ago, a step forward in the characterization of the human NK cell developmental pathway was done by Caligiuri and colleagues, by defining a five-stage model of human NK cell development in SLT [91,92]. In this study, and based on the differential expression of CD34, CD117, CD94, and CD16, five human NK cell developmental stages were defined as follows: stage $1 \mathrm{CD} 34^{+} \mathrm{CD} 117^{-} \mathrm{CD} 94^{-} \mathrm{CD} 16^{-}$, stage $2 \mathrm{CD}^{-} 4^{+} \mathrm{CD} 117^{+} \mathrm{CD} 94^{-} \mathrm{CD} 16^{-}$, stage $3 \mathrm{CD}^{-} 4^{-} \mathrm{CD} 117^{+} \mathrm{CD} 94^{-} \mathrm{CD}^{-} 6^{-}$, stage $4 \mathrm{CD} 34^{-} \mathrm{CD} 117^{+/-} \mathrm{CD}^{+} 4^{+} \mathrm{CD} 16^{-}$, and stage $5 \mathrm{CD}^{-} 4^{-} \mathrm{CD} 117^{-} \mathrm{CD}^{+/-} 4^{+-} \mathrm{CD} 16^{+}$[93]. In this model, cells comprising stages 1 and 2 are capable to differentiate into dendritic cells (DCs), T cells, and NK cells, while stage 3 cells can give rise to NK cells but not to DCs or T cells. Thus, stage 3 cells are considered lineage-restricted NK cell precursors. The acquisition of CD122 (IL-2/15 receptor $\beta$-chain) marks an important step towards NK cell differentiation as the trans-presentation of soluble IL-15 is essential for mature NK cell survival $[77,78,94]$. However, functional maturity is not acquired until stage 4 , as stage 3 cells are characterized by the lack of key mature NK cell features, such as, IFN $\gamma$ production and perforin-mediated cytotoxicity $[93,95]$.

Subsequent studies have described additional differentiation steps of this model. For instance, using 10-parameters flow cytometry, Eissen et al. defined 7 human NK cell developmental stages in the bone marrow, adding a layer of complexity. They propose that stage 3 can be subdivided in two additional stages distinguished by NK cell lineage commitment acquisition through CD56 expression, stage $3 \mathrm{a}\left(\mathrm{CD} 34^{-} \mathrm{CD} 117^{+} \mathrm{CD} 94^{-} \mathrm{CD}^{-} 6^{-}\right)$and stage $3 \mathrm{~b}$ $\left(\mathrm{CD} 34^{-} \mathrm{CD} 117^{+} \mathrm{CD} 94^{-} \mathrm{CD} 56^{+}\right)$. Moreover, they also divided stage 5 in two more stages,

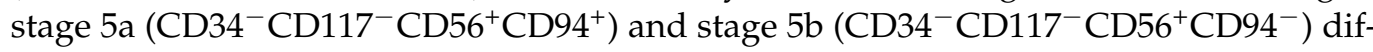
ferentiated by the loss of CD94 expression [80]. In addition, Scoville et al. proposed that SLT stage 2 cells can be divided in two functionally distinct subsets according to surface expression of the IL-1 $\beta$ receptor (IL-1R1) and suggest that stage $2 b$ IL-1R1+ cells represent common ILC progenitors (CILP) in humans [96,97]. Furthermore, two different steps of stage 4 have been described also in SLT, differing in the C-type lectin-like activating receptor NKp80 expression. Stage 4a subset was NKp80- and characterized by ILC3-associated features and not significant effector functions, while stage $4 \mathrm{~b}$ subset was NKp80+ and cells produced IFN $\gamma$ and mediated perforin-dependent cytotoxicity [95]. These stage $4 \mathrm{~b}$ cells are thought to represent CD56 $6^{\text {bright }} \mathrm{NK}$ cells, whereas stage 5 cells represent the CD56 ${ }^{\text {dim }}$ NK cell subset. Thus, according to this linear model of NK cell development, there is 
a transition from CD56 bright to CD56 dim defined by, among others, downregulation of CD56 and acquisition of CD16 [84,98]. However, this step is probably controversial, as the existence of CD56 ${ }^{\mathrm{dim}} \mathrm{NK}$ cells was reported in primary immunodeficiency patients that lack CD56 ${ }^{\text {bright }}$ NK cells [99]. Nevertheless, the generation of CD56 ${ }^{\mathrm{dim}} \mathrm{NK}$ cells from CD56 bright NK cells when human HSCs are engrafted in humanized mice [77], the fact that CD56 $6^{\text {bright }}$ NK cells display longer telomeres [100] and that CD56 $6^{\text {bright }}$ NK cells are the predominant population after HSCT [101], among others, supports the hypothesis for a developmental relationship between CD56 $6^{\text {bright }}$ and CD56 ${ }^{\text {dim }}$ NK cells.

CD56 ${ }^{\mathrm{dim}} \mathrm{NK}$ cells are a very heterogeneous population and are further differentiated until stage 6, defined by the acquisition of CD57, thus being considered terminally differentiated NK cells $[102,103]$. Through this final differentiation step, CD56 ${ }^{\mathrm{dim}}$ NK cells loss NKG2A expression and sequentially acquire KIRs and CD57. CD57 expression increases with the expression of KIRs and correlate inversely with the expression of NKG2A. Moreover, they experience a gradual decline in proliferative capacity, along with different expression patterns of homing molecules $[104,105]$. Terminally differentiated NK cells are less responsive to stimulation by cytokines, but produce IFN $\gamma$ and have a potent lytic activity when stimulated via CD16, evidencing a gradual shift in functionality during differentiation [103].

Although these NK cell developmental steps are well accepted, NK cell development is a more intricate process. For instance, different studies have revealed the existence of multiple cellular intermediates, such as unconventional CD56 ${ }^{\mathrm{dim}} \mathrm{CD} 16^{-} \mathrm{NK}$ cells [31] and CD56 bright $C D 16^{+}$NK cells [106]. Moreover, although in lower frequencies, it is possible to find all combinations of NKG2A and KIR expression in either CD57+ or CD57- CD56 dim NK cells [104]. Thus, it is obvious that the linear model of NK cell development is only an oversimplification of what really happens. Finally, little is known about the developmental origin of other NK cell subsets, such as adaptive NK cells [107] or CD56 ${ }^{\text {neg }}$ NK cells, opening the possibility of yet not explored differentiation pathways.

\section{The Role of NK Cells in Autologous Hematopoietic Stem Cell Transplantation \\ 5.1. Hematopoietic Stem Cell Transplantation: Types and Indications}

HSCT is a worldwide-established treatment option for many hematological disorders. In this type of cell immunotherapy, after the administration of an appropriate conditioning regimen that will ablate the recipient's own bone marrow and induce sufficient immunosuppression to allow engraftment, HSCs are infused to replace the recipient's unhealthy native bone marrow cells and immune system.

HSCT can be classified in different types based on the relationship between donor and recipient and the source of the graft. Thus, HSCT can be classified as autologous HSCT (autoHSCT), when the patient's own stem cells are collected and reinfused at a later time, or alloHSCT, when HSCs come from another individual. In this latter scenario, donors can be related or unrelated HLA-matched. Moreover, when such donor cannot be found, umbilical cord blood (CB) or a related half-matched donor, also known as haploidentical transplantation, in which only one of the two HLA haplotypes is matched, can be used. On the other hand, according to the source, HSCs can be obtained from bone marrow, peripheral blood, or CB. Although HSCs were first harvested from bone marrow, nowadays and due to the development of mobilization procedures, such as the use of granulocyte colony-stimulating factor (G-CSF), peripheral blood is the main source of precursors $[108,109]$.

In 2012, a total of 68,146 HSCTs were reported worldwide. Among them, $47 \%$ were allogenic and 53\% autologous [110]. Moreover, in 2018, 47,468 transplants were reported only in Europe. Of these, $41 \%$ were allogenic and 59\% autologous. In Europe, the main indications for alloHSCT are myeloid malignancies, being AML the largest indication, while, the main indications for autoHSCT are lymphoid malignancies, being multiple myeloma (MM) and non-Hodgkin lymphoma (NHL) the largest indications [111]. 


\subsection{Factors Affecting autoHSCT Outcome}

The benefits of alloHSCT go beyond the recovery from bone marrow aplasia after conditioning regimen, as immune cells in the graft might recognize and eliminate residual malignant cells, which is known as graft-versus-tumor (GvT) effect. Conversely, for years, autoHSCT has only been seen as a form for bone marrow rescue, necessary for hematologic engraftment, and its antitumor effect has been thought to rely on the conditioning regimen. Nevertheless, studies carried out in the last 15-20 years pointed out that a GvT effect might also be possible in autoHSCT setting [112]. As in alloHSCT, early immune recovery after autoHSCT has been associated with prolonged survival in a wide range of hematological malignancies [113-116]. Particularly, day 15 absolute lymphocyte count (ALC-15) of $\geq 500$ cells $/ \mu \mathrm{L}$ after autoHSCT was reported as an independent prognostic indicator for overall survival (OS) and progression-free survival (PFS) in MM and NHL patients [114]. Moreover, while different studies have not found any correlation between CD34+ cells dose and absolute lymphocyte count (ALC) recovery [117-119], a strong correlation was identified between the number of passively infused lymphocytes in the peripheral blood autograft (A)-ALC and ALC-15, being A-ALC higher in patients achieving an ALC-15 of $\geq 500$ cells $/ \mu \mathrm{L}$ [120]. The amount of passively transferred lymphocytes correlated inversely with the time to achieve a lymphocyte count of $0.5 \times 10^{9}$ cells/L [118]. Furthermore, A-ALC was reported to be an independent prognostic factor for OS and PFS, in NHL patients [120]. $\mathrm{T}$ cells and NK cells were the main lymphocyte subsets identified in the autograft, and among them, a strong correlation was found between NK cells absolute numbers from the apheresis product and ALC-15 [117]. After that, NK cells were identified as the key lymphocyte subset in ALC-15 that impacted the outcome after autoHSCT. Thus, NHL patients with NK cell count at day 15 (NK-15) of $\geq 80$ cells $/ \mu \mathrm{L}$ experienced superior 3-year OS and PFS [121] and MM patients with NK cell count at 1 month of $\geq 100$ cells $/ \mu \mathrm{L}$ experienced prolonged PFS [122] than patients with lower counts. In addition, NHL patients with IL-15 levels $\geq 76.5 \mathrm{pg} / \mathrm{mL}$ at day 15 post-autoHSCT experienced superior 3-year OS and PFS compared with those patients with lower IL-15 levels. However, this survival benefit was reported to be most likely mediated by enhanced NK cell recovery after transplant [123]. Although all these are circumstantial evidences, and thus do not prove causality, they all suggest that the infusion of autograft lymphocytes does impact not only on immune reconstitution but also on the clinical outcome after autoHSCT (Table 2). Residual disease progression may be controlled by an early immune reconstitution and passively infused lymphocytes, opening the possibility for an autologous GvT effect $[124,125]$.

Table 2. Factors affecting autologous hematopoietic stem cell transplantation (autoHSCT) outcome.

\begin{tabular}{|c|c|c|c|}
\hline Factors & Prognostic Indicator for & Pathology & References \\
\hline $\begin{array}{l}\text { Absolute lymphocyte count at day } \\
15 \text { (ALC-15) }\end{array}$ & OS, PFS & Breast cancer, MM, NHL, HL, AML. & [113-116] \\
\hline $\begin{array}{l}\text { Autograft absolute lymphocyte } \\
\text { count (A-ALC) }\end{array}$ & OS, PFS & NHL & [120] \\
\hline NK cell count at day 15 (NK-15) & OS, PFS & NHL & [121] \\
\hline NK cell count at 1 month & PFS & MM & [122] \\
\hline IL-15 levels at day 15 & OS, PFS & NHL & [123] \\
\hline HLA-Cw8 genotype & OS & Lymphoma & [126] \\
\hline KIR-HLA receptor-ligand mismatch & Disease progression & $\begin{array}{l}\text { Lymphoma, solid tumor, } \\
\text { neuroblastoma }\end{array}$ & {$[127,128]$} \\
\hline $\begin{array}{l}\text { KIR and HLA genotypes predictive } \\
\text { of low-affinity interactions }\end{array}$ & Relapse & AML & [129] \\
\hline KIR3DS1 genotype & PFS & $\begin{array}{l}\text { MM in complete response or partial } \\
\text { remission at autoHSCT }\end{array}$ & [130] \\
\hline
\end{tabular}

AML: acute myeloid leukemia; HL: Hodgkin lymphoma; IL-15: interleukin 15; MM: multiple myeloma; NHL: non-Hodgkin lymphoma; OS: overall survival; PFS: progression free survival. 


\subsection{Immune Reconstitution after autoHSCT and the Relevance of NK Cells}

After HSCT, clinical engraftment is commonly considered when achieving a peripheral blood neutrophil count of $>0.5 \times 10^{9} / \mathrm{L}$ [131]. However, this does not mean that complete immune reconstitution occurs at this point. Reconstitution of immunologically competent effector cells occurs very gradually and more than a year may be needed to restore normal humoral and cellular immunity. Of note, B cells are barely detectable during the first 2-3 months post-HSCT, and the recovery of normal B cell numbers and functions can take up to 18 months [125]. Moreover, T cell recovery is also delayed, being CD8+ T cells' restoration faster than $\mathrm{CD} 4+\mathrm{T}$ cells, as the latter may fully reconstitute after 1-year post-HSCT. Thus, an inverted CD4/CD8 ratio is reported after HSCT [125].

In contrast, NK cells have been reported to be the first lymphocyte subset to return to normal levels, being the counts and functionality of NK cells restored as early as day 14 postHSCT $[125,132]$. Considering that NK cells can display anti-tumor function independently of prior sensitization, play a role in immune surveillance and recover early after $\mathrm{HSCT}$, the study of the reconstitution of these cells in autoHSCT settings is of utmost interest. Moreover, methods to improve NK cell recovery and post-HSCT immunomodulation targeting NK activity may also be of great interest. As mentioned before, the GvT effect exerted by NK cells in alloHSCT mainly relies in a mismatch between KIRs expressed by donor NK cells and the HLA class I ligands expressed on the recipient's tumor cells [133,134]. As genes that encode KIRs and their HLA class I ligands segregate independently, expression of inhibitory KIRs but not its corresponding ligands, and vice versa, may happen. Although NK cells expressing inhibitory KIRs for non-self HLA molecules are hyporesponsive in steady state, in certain situations like inflammation, they may become responsive and play biologically important roles [135,136]. Thus, even though far less reported and studied, inhibitory KIR-HLA receptor-ligand mismatch can also occur in autoHSCT and affects patient's outcome (Table 2). HLA-Cw8 was reported to be an independent risk factor for poor outcome in lymphoma patients undergoing autoHSCT [126]. Moreover, lower risk of relapse was found when inhibitory KIR-HLA receptor ligand mismatch occur in a cohort of patients undergoing autoHSCT for solid tumor and lymphoma [127]. A similar outcome was also seen in patients undergoing autoHSCT for high-risk neuroblastoma. Particularly, patients lacking HLA-C1, the ligand for KIR2DL2/KIR2DL3, have the highest 3-years survival rate [128]. However, Stern and colleagues were not able to show that missing KIR-ligand effect in their autoHSCT cohort [137]. This is probably due to the fact that, in contrast to Leung et al., they grouped patients exclusively based on the presence or absence of KIR ligands and did not take into account inhibitory KIRs expression. In a cohort of AML patients treated with autoHSCT, those with KIR and HLA genotypes predictive of low-affinity interactions (KIR3DL1+ and HLA-Bw4-80Thr ${ }^{+}, H L A-B w 4-80 I l e^{-}$genotype) had lower incidence of relapse than patients with genotypes predictive of high-affinity interactions (KIR3DL1+ and HLA-Bw4-80Ile ${ }^{+}$genotype), and this effect was also influenced by HLA-Bw4 copy number [129]. This can be explained because HLA-Bw4-80Thr molecules bind KIR3DL1 with lower affinity than HLA-Bw4-80Ile, endowing lower responsiveness but weaker NK cell inhibition [129,138]. Finally, MM patients who were KIR3DS1+ (activating KIR encoding gene) experienced shorter PFS after autoHSCT and this was more evident in patients that were at complete or partial remission at transplantation and who lacked the ligand for the inhibitory KIR3DL1, i.e., HLA-Bw4 [130]. Although the mechanism by which KIR3DS1 affects patient's survival is not well understood, one possible explanation for its negative impact could be that KIR3DS1+ NK clones may exert an immunomodulatory effect of antitumor responses by the production of anti-inflammatory cytokines [130]. On the other hand, it has been suggested that KIR3DS1 accomplish a protective role in other human diseases [139]. Thus, this KIR might have either detrimental or beneficial effect depending on the type of disease.

As KIRs are just a minor part of the complex NK cell receptor repertoire, the study of further receptors, as well as the reconstitution of different NK cell subsets that might be implicated in the survival of patients undergoing autoHSCT is of great importance. In 
this sense, recently, whether a particular immune signature was associated with long-term complete response in MM patients was investigated. The authors found that, even if the frequency of NK cells within total lymphocytes was similar in patients and healthy donors, higher frequency of the inhibitory receptor KIR2DL1-expressing NK cells, higher frequency of NKG2A+ NK cells and lower frequency of NKp46+ NK cells were observed in MM patients in long-term complete response. Thus, a particular redistribution of NK cell activating and inhibitory receptors occurs in these patients [140]. In another recent study, Bhutani et al. examined the differences in terms of NK cell numbers and phenotype between MM patients with minimal residual disease (MRD) positive status versus MRD negative status after autoHSCT. These authors found that absolute numbers of NK cells were lower in patients with MRD positive response. In addition, and although the differences were not statistically significant, these patients have a higher frequency of KIRDS4+ NK cells and a lower frequency of NKG2A+ NK cells compared to patients with MRDnegative response [141]. Moreover, a few years ago, a comprehensive study of different NK cell subsets, their phenotype, and their function at three different time points, i.e., before autoHSCT (T1), after leukocyte regeneration (T2), and after 2 weeks of leukocyte recovery (T3), in patients undergoing autoHSCT was carried out (Figure 2) [142]. In this study, authors found that the frequency of NK cells within the leukocyte population significantly decreases from T1 to T2 but then recovered to the pre-autoHSCT levels at T3. Furthermore, the fold change ratio T2/T1 of the NK cell percentage was different between patients having a period time of $\leq 11$ days between autoHSCT and T2 and those having a period of $>11$ days and also in patients with recurrent or refractory disease and those without. Focusing on NK cell subsets, they observed that CD56 ${ }^{\operatorname{dim}}\left(\mathrm{CD} 56^{+} \mathrm{CD} 16^{++}\right)$subset was the main population at T1 and T3. However, NK cell subsets redistribution was observed at $\mathrm{T} 2$, in which the frequency of CD56 $6^{\mathrm{dim}}$ decreased, while the two populations of CD56 $6^{\text {bright }}$ that they distinguish $\left(\mathrm{CD} 56^{++} \mathrm{CD} 16^{-}\right.$and $\left.\mathrm{CD} 56^{++} \mathrm{CD} 16^{+}\right)$significantly increased, being the percentage of $\mathrm{CD} 56^{\text {bright }} \mathrm{CD} 16^{+}$subset similar to the one of $\mathrm{CD} 56^{\mathrm{dim}}$ subset. The NK cell subset distribution at $\mathrm{T} 3$, although similar to the one observed at $\mathrm{T} 1$, was not the same. In addition, they studied the expression of NKG2A, CD57, and KIRs, i.e., markers related to NK cell differentiation and education. They found that on total NK cells, the frequency of NKG2A+ NK cell increased from T1 to T2 and was maintained elevated at T3. Furthermore, the expression of CD57 also increased from $\mathrm{T} 1$ to $\mathrm{T} 2$ but then recover to the initial levels at T3. A similar pattern of expression was also observed when the three subsets were separately analyzed. Particularly, the expression of CD57 at T2 in both CD56 ${ }^{\text {bright }}$ subsets was surprising, as CD57 is considered a marker of terminally differentiation and CD56 $6^{\text {bright }}$ are thought to be immature NK cells. In contrast, the frequency of KIR-expressing NK cells remains constant during NK cell reconstitution, even though the percentage of KIR+ cells in both CD56 $6^{\text {bright }}$ subsets increased at T2 and maintained elevated at T3 (Figure 2). The elevated frequency of both CD57 and KIRs in CD56 bright subsets was found to be age dependent. They also performed an exhaustive study of different KIRs revealing that KIR2DL2/3/S2 and KIR3DL1 were upregulated in both CD56 ${ }^{\text {bright }}$ subsets from T1 to T2 and that while KIR2DL2/3/S2 was the dominant KIR subset expressed at T1 on CD56 ${ }^{\text {bright }} \mathrm{CD} 16^{-} \mathrm{NK}$ cells, KIR3DL1 was the dominant one at T2. In contrast, KIR2DL1/S1 levels remained constant. This pattern of KIR expression, in which KIR2DL2/3 and KIR3DL1 are the first KIRs appearing after HSCT, while KIR2DL1 is upregulated later, have been also observed in alloHSCT $[143,144]$. Finally, when effector functions of NK cells were assessed, Jacobs et al. reported that NK cells were able to degranulate (CD107a) and to produce cytokines (IFN $\gamma$ ) and chemokines (MIP1 $\beta$ ) upon target cell recognition early after autoHSCT [142]. As the cohort of patients analyzed in this study is quite heterogeneous in terms of the type of cancer, it must be elucidated whether the NK cell subsets distribution, their phenotype and functionality during NK cell reconstitution will be the same in a particular hematological malignancy. In this sense, Jacobs et al. also found some differences regarding the CD56 ${ }^{\text {dim }} / \mathrm{CD} 56^{\text {bright }}$ ratio and the frequency of CD56 $6^{\text {bright }} \mathrm{NKG} \mathrm{A}^{+}$cells at T2 between MM and lymphoma patients undergoing autoHSCT [142]. Analysis of different 
NK cell subsets distribution was also carried out in a cohort of MM undergoing autoHSCT. In this case, the authors found that a population of CD56 ${ }^{\text {dim }} C D 16^{\text {low }}$ was expanded after 2 weeks post-transplant and returned to initial levels after a month post-HSCT. They also described that this subset displayed the highest capacity to degranulate in vitro against K562 and MM cell lines [145]. Thus, it would be highly valuable to elucidate whether this subset plays a fundamental role in the GvT effect and in the outcome of MM patients after autoHSCT. Furthermore, an exhaustive analysis of other NK cell subsets that have been associated with survival in patients undergoing alloHSCT is also needed in an autoHSCT setting. This is, e.g., the case of adaptive NK cells and CD56 ${ }^{\text {neg }}$ NK cells. In studies performed with alloHSCT recipients, it has been suggested that CMV-expanded NKG2C+ NK cell population may exert anti-leukemic effect. There have been also described that early human CMV reactivation after allogenic HSCT was associated with reduced risk for relapse [146-151]. Moreover, adaptive NK cell expansion was associated with lower relapse in different HSCT settings [152,153]. In addition, an expansion of CD56 ${ }^{\text {neg }}$ NK cells after different HSCT settings have been described [154-156]. In T cell-depleted haploidentical HSCT, CD56 ${ }^{\text {neg }}$ appear to be functional and capable of GvT effect [156].

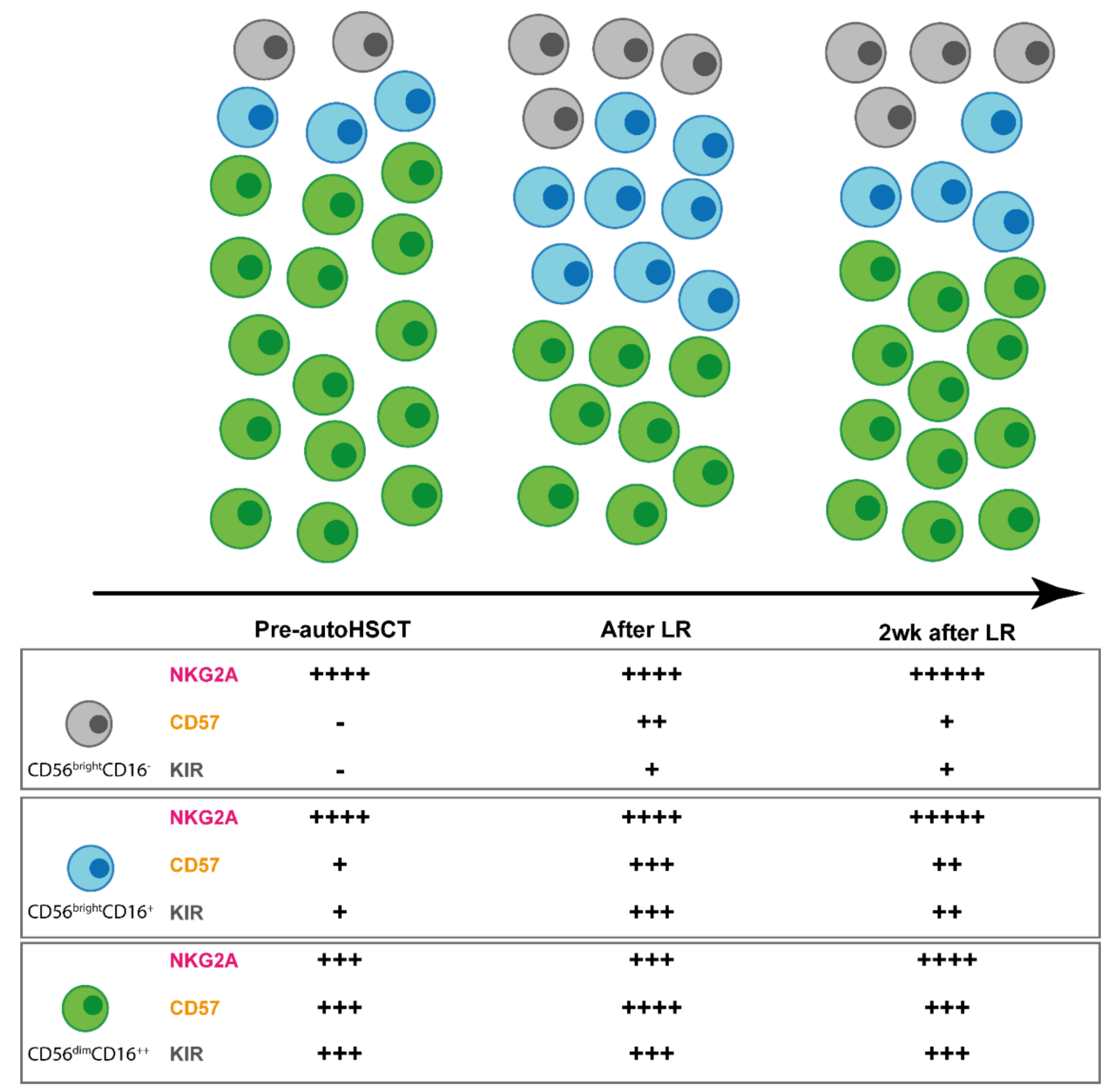

Figure 2. NK cell subset and receptor repertoire redistribution during NK cell reconstitution after autologous hematopoietic stem cell transplantation (autoHSCT). The distribution of the three NK cell subsets (CD56 ${ }^{\text {bright }} \mathrm{CD} 16^{-}, \mathrm{CD}^{\mathrm{b}}{ }^{\text {bright }} \mathrm{CD} 16^{+}$, and $\mathrm{CD} 56^{\mathrm{dim}} \mathrm{CD} 16^{++}$) changes significantly at leucocyte recovery and some changes are still evident 2 weeks after leucocyte recovery. Moreover, the frequency of NK cells expressing the surface receptors NKG2A, CD57, and KIR in the different NK cell subsets is also altered. The frequency of NKG2A+, CD57+, and killer cell immunoglobulin-like receptors (KIR)+ NK cells within each subset is represented with the + symbol. After LR: after leucocyte recovery; 2 weeks after LR: 2 wk after leucocyte recovery. 
Since NK cells seem to play a fundamental role early after autoHSCT, different therapeutic approaches have been used trying to enhance NK cell functional activity early after autoHSCT. Among others, the administration of IL-2 after autoHSCT has been studied. In general, significant increase in NK cell counts were observed. Moreover, in vitro enhanced NK cell cytotoxic activity was observed when compared to controls $[157,158]$. However, even though IL-2-based immunotherapy can be safely administrated after autoHSCT, it failed to demonstrate improvement in the disease outcome $[157,159,160]$. In addition, infusion of haploidentical or CB-derived NK cells in the setting of autoHSCT has been also studied [161-165]. Although the infusion of these NK cells seems to be well-tolerated, future studies regarding survival benefits of these treatment strategies are needed. Thus, in-depth studies of currently available therapies and of additional strategies targeting NK cells and enhancing their anti-tumor effector functions would be worth to explore [166].

\section{Concluding Remarks}

NK cells reconstitution, as opposed to what happens to other lymphocytes, occurs early after autoHSCT. Moreover, as several studies have shown, not only the NK cell count after autoHSCT have an impact on patient's outcome but also the reconstitution of different NK cells subsets and their phenotype may be of great importance. For this reason, studies analyzing other NK cells subsets rather than the conventional CD56 $6^{\text {bright }}$ and CD56 $6^{\mathrm{dim}}$ subpopulations, in addition to other aspects of NK cells phenotype will contribute to the better understanding of NK cell reconstitution after autoHSCT. These studies may also be helpful to identify new biomarkers that may predict HSCT outcomes, allowing individualizing and further improving this therapy. Furthermore, although the GvT effect mediated by NK cells has been well-defined in alloHSCT, in-depth studies are also needed to clarify this point in autoHSCT. Thus, there are still unsolved questions regarding the potential beneficial role that NK cells may have in autoHSCT settings that are worthy to explore.

Author Contributions: Writing—original draft preparation, Review and Editing, A.O., I.T., G.A.-P., O.Z. and F.B. All authors have made a substantial, direct and intellectual contribution to the work, and approved it for publication. All authors have read and agreed to the published version of the manuscript.

Funding: Supported by the following grants: AECC-Spanish Association Against Cancer (PROYE160 74BORR) and Health Department, Basque Government (2020333024). A.O. and G.A.-P. are recipient of a fellowship from the Jesús de Gangoiti Barrera Foundation (FJGB20/007 and FJGB20/002). I.T. is recipient of a predoctoral contract funded by the Department of Education, Basque Government (PRE_2020_2_0007). O.Z. is recipient of a postdoctoral contract funded by “Instituto de Salud Carlos III-Contratos Sara Borrell 2017 (CD17/00128)" and the European Social Fund (ESF)-The ESF invests in your future. F.B. is an Ikerbasque Research Professor, Ikerbasque, Basque Foundation for Science.

Data Availability Statement: The data presented in this study are available on request from the corresponding author.

Conflicts of Interest: The authors declare that the research was conducted in the absence of any commercial or financial relationships that could be construed as a potential conflict of interest.

\section{References}

1. Mjösberg, J.; Spits, H. Human innate lymphoid cells. J. Allergy Clin. Immunol. 2016, 138, 1265-1276. [CrossRef]

2. Vivier, E.; Artis, D.; Colonna, M.; Diefenbach, A.; Di Santo, J.P.; Eberl, G.; Koyasu, S.; Locksley, R.M.; McKenzie, A.N.J.; Mebius, R.E.; et al. Innate Lymphoid Cells: 10 Years On. Cell 2018, 174, 1054-1066. [CrossRef] [PubMed]

3. Krabbendam, L.; Bernink, J.H.; Spits, H. Innate lymphoid cells: From helper to killer. Curr. Opin. Immunol. 2021, 68, 28-33. [CrossRef] [PubMed]

4. Guillerey, C. Roles of cytotoxic and helper innate lymphoid cells in cancer. Mamm. Genome 2018, 29, 777-789. [CrossRef] [PubMed]

5. Spits, H.; Bernink, J.H.; Lanier, L. NK cells and type 1 innate lymphoid cells: Partners in host defense. Nat. Immunol. 2016, 17, 758-764. [CrossRef] [PubMed]

6. Cortez, V.S.; Colonna, M. Diversity and function of group 1 innate lymphoid cells. Immunol. Lett. 2016, 179, 19-24. [CrossRef] 
7. Björklund, Å.K.; Forkel, M.; Picelli, S.; Konya, V.; Theorell, J.; Friberg, D.; Sandberg, R.; Mjösberg, J. The heterogeneity of human CD127+ innate lymphoid cells revealed by single-cell RNA sequencing. Nat. Immunol. 2016, 17, 451-460. [CrossRef]

8. Simoni, Y.; Newell, E.W. Dissecting human ILC heterogeneity: More than just three subsets. Immunology 2018, 153, 297-303. [CrossRef]

9. Gao, Y.; Souza-Fonseca-Guimaraes, F.; Bald, T.; Foong, N.S.; Young, A.; Ngiow, S.F.; Rautela, J.; Straube, J.; Waddell, N.; Blake, S.J.; et al. Tumor immunoevasion by the conversion of effector NK cells into type 1 innate lymphoid cells. Nat. Immunol. 2017, 18, 1004-1015. [CrossRef] [PubMed]

10. Seillet, C.; Brossay, L.; Vivier, E. Natural killers or ILC1s? That is the question. Curr. Opin. Immunol. 2021, 68, 48-53. [CrossRef] [PubMed]

11. Prager, I.; Watzl, C. Mechanisms of natural killer cell-mediated cellular cytotoxicity. J. Leukoc. Biol. 2019, 105, 1319-1329. [CrossRef]

12. Lopez, J.A.; Susanto, O.; Jenkins, M.R.; Lukoyanova, N.; Sutton, V.R.; Law, R.H.P.; Johnston, A.; Bird, C.H.; Bird, P.I.; Whisstock, J.C.; et al. Perforin forms transient pores on the target cell plasma membrane to facilitate rapid access of granzymes during killer cell attack. Blood 2013, 121, 2659-2668. [CrossRef]

13. Chowdhury, D.; Lieberman, J. Death by a Thousand Cuts: Granzyme Pathways of Programmed Cell Death. Annu. Rev. Immunol. 2008, 26, 389-420. [CrossRef] [PubMed]

14. von Karstedt, S.; Montinaro, A.; Walczak, H. Exploring the TRAILs less travelled: TRAIL in cancer biology and therapy. Nat. Rev. Cancer 2017, 17, 352-366. [CrossRef] [PubMed]

15. Peter, M.E.; Krammer, P.H. The CD95(APO-1/Fas) DISC and beyond. Cell Death Differ. 2003, 10, 26-35. [CrossRef] [PubMed]

16. Jorgovanovic, D.; Song, M.; Wang, L.; Zhang, Y. Roles of IFN- $\gamma$ in tumor progression and regression: A review. Biomark. Res. 2020, 8, 49. [CrossRef]

17. Vivier, E.; Tomasello, E.; Baratin, M.; Walzer, T.; Ugolini, S. Functions of natural killer cells. Nat. Immunol. 2008, 9, 503-510. [CrossRef]

18. Kim, S.; Iizuka, K.; Aguila, H.L.; Weissman, I.L.; Yokoyama, W.M. In vivo natural killer cell activities revealed by natural killer cell-deficient mice. Proc. Natl. Acad. Sci. USA 2000, 97, 2731-2736. [CrossRef]

19. Cerwenka, A.; Baron, J.L.; Lanier, L.L. Ectopic expression of retinoic acid early inducible-1 gene (RAE-1) permits natural killer cell-mediated rejection of a MHC class I-bearing tumor in vivo. Proc. Natl. Acad. Sci. USA 2001, 98, 11521-11526. [CrossRef]

20. Diefenbach, A.; Jensen, E.R.; Jamieson, A.M.; Raulet, D.H. Rae1 and H60 ligands of the NKG2D receptor stimulate tumour immunity. Nat. Cell Biol. 2001, 413, 165-171. [CrossRef]

21. Imai, K.; Matsuyama, S.; Miyake, S.; Suga, K.; Nakachi, K. Natural cytotoxic activity of peripheral-blood lymphocytes and cancer incidence: An 11-year follow-up study of a general population. Lancet 2000, 356, 1795-1799. [CrossRef]

22. Hsu, K.C.; Keever-Taylor, C.A.; Wilton, A.; Pinto, C.; Heller, G.; Arkun, K.; O’Reilly, R.J.; Horowitz, M.M.; Dupont, B. Improved outcome in HLA-identical sibling hematopoietic stem-cell transplantation for acute myelogenous leukemia predicted by KIR and HLA genotypes. Blood 2005, 105, 4878-4884. [CrossRef]

23. Cooper, M.A.; Fehniger, T.A.; Caligiuri, M.A. The biology of human natural killer-cell subsets. Trends Immunol. 2001, 22, 633-640. [CrossRef]

24. Schwane, V.; Huynh-Tran, V.H.; Vollmers, S.; Yakup, V.M.; Sauter, J.; Schmidt, A.H.; Peine, S.; Altfeld, M.; Richert, L.; Körner, C. Distinct Signatures in the Receptor Repertoire Discriminate CD56bright and CD56dim Natural Killer Cells. Front. Immunol. 2020, 11, 568927. [CrossRef] [PubMed]

25. Freud, A.G.; Mundy-Bosse, B.L.; Yu, J.; Caligiuri, M.A. The Broad Spectrum of Human Natural Killer Cell Diversity. Immunity 2017, 47, 820-833. [CrossRef] [PubMed]

26. Michel, T.; Poli, A.; Cuapio, A.; Briquemont, B.; Iserentant, G.; Ollert, M.; Zimmer, J. Human CD56bright NK Cells: An Update. J. Immunol. 2016, 196, 2923-2931. [CrossRef]

27. Wagner, J.A.; Rosario, M.; Romee, R.; Berrien-Elliott, M.M.; Schneider, S.E.; Leong, J.W.; Sullivan, R.P.; Jewell, B.A.; Becker-Hapak, M.; Schappe, T.; et al. CD56bright NK cells exhibit potent antitumor responses following IL-15 priming. J. Clin. Investig. 2017, 127, 4042-4058. [CrossRef]

28. Poznanski, S.M.; Nham, T.; Chew, M.V.; Lee, A.J.; Hammill, J.A.; Fan, I.Y.; Butcher, M.; Bramson, J.L.; Lee, D.A.; Hirte, H.W.; et al. Expanded CD56superbrightCD16+ NK Cells from Ovarian Cancer Patients Are Cytotoxic against Autologous Tumor in a Patient-Derived Xenograft Murine Model. Cancer Immunol. Res. 2018, 6, 1174-1185. [CrossRef]

29. Fauriat, C.; Long, E.O.; Ljunggren, H.-G.; Bryceson, Y.T. Regulation of human NK-cell cytokine and chemokine production by target cell recognition. Blood 2010, 115, 2167-2176. [CrossRef]

30. De Maria, A.; Bozzano, F.; Cantoni, C.; Moretta, L. Revisiting human natural killer cell subset function revealed cytolytic CD56dimCD16+ NK cells as rapid producers of abundant IFN- on activation. Proc. Natl. Acad. Sci. USA 2011, 108, 728-732. [CrossRef]

31. Roberto, A.; Di Vito, C.; Zaghi, E.; Mazza, E.M.C.; Capucetti, A.; Calvi, M.; Tentorio, P.; Zanon, V.; Sarina, B.; Mariotti, J.; et al. The early expansion of anergic NKG2A pos /CD56 dim /CD16 neg natural killer represents a therapeutic target in haploidentical hematopoietic stem cell transplantation. Haematologica 2018, 103, 1390-1402. [CrossRef] [PubMed]

32. Castriconi, R.; Carrega, P.; Dondero, A.; Bellora, F.; Casu, B.; Regis, S.; Ferlazzo, G.; Bottino, C. Molecular Mechanisms Directing Migration and Retention of Natural Killer Cells in Human Tissues. Front. Immunol. 2018, 9, 2324. [CrossRef] 
33. Horowitz, A.; Strauss-Albee, D.M.; Leipold, M.; Kubo, J.; Nemat-Gorgani, N.; Dogan, O.C.; Dekker, C.L.; Mackey, S.; Maecker, H.; Swan, G.E.; et al. Genetic and Environmental Determinants of Human NK Cell Diversity Revealed by Mass Cytometry. Sci. Transl. Med. 2013, 5, 208ra145. [CrossRef] [PubMed]

34. Smith, S.L.; Kennedy, P.R.; Stacey, K.B.; Worboys, J.D.; Yarwood, A.; Seo, S.; Solloa, E.H.; Mistretta, B.; Chatterjee, S.S.; Gunaratne, P.; et al. Diversity of peripheral blood human NK cells identified by single-cell RNA sequencing. Blood Adv. 2020, 4, 1388-1406. [CrossRef]

35. Björkström, N.K.; Ljunggren, H.-G.; Michaëlsson, J. Emerging insights into natural killer cells in human peripheral tissues. Nat. Rev. Immunol. 2016, 16, 310-320. [CrossRef]

36. Evans, J.H.; Horowitz, A.; Mehrabi, M.; Wise, E.L.; Pease, J.E.; Riley, E.M.; Davis, D.M. A distinct subset of human NK cells expressing HLA-DR expand in response to IL-2 and can aid immune responses to BCG. Eur. J. Immunol. 2011, 41, 1924-1933. [CrossRef] [PubMed]

37. Erokhina, S.A.; Streltsova, M.A.; Kanevskiy, L.M.; Telford, W.G.; Sapozhnikov, A.M.; Kovalenko, E.I. HLA-DR+ NK cells are mostly characterized by less mature phenotype and high functional activity. Immunol. Cell Biol. 2018, 96, 212-228. [CrossRef]

38. Grzywacz, B.; Kataria, N.; Sikora, M.; Oostendorp, R.A.; Dzierzak, E.A.; Blazar, B.R.; Miller, J.S.; Verneris, M.R. Coordinated acquisition of inhibitory and activating receptors and functional properties by developing human natural killer cells. Blood 2006, 108, 3824-3833. [CrossRef]

39. Ostrowski, S.R.; Ullum, H.; Pedersen, B.K.; Gerstoft, J.; Katzenstein, T.L. 2B4 expression on natural killer cells increases in HIV-1 infected patients followed prospectively during highly active antiretroviral therapy. Clin. Exp. Immunol. 2005, 141, 526-533. [CrossRef]

40. Peng, H.; Tian, Z. Diversity of tissue-resident NK cells. Semin. Immunol. 2017, 31, 3-10. [CrossRef]

41. Crinier, A.; Milpied, P.; Escalière, B.; Piperoglou, C.; Galluso, J.; Balsamo, A.; Spinelli, L.; Cervera-Marzal, I.; Ebbo, M.; GirardMadoux, M.; et al. High-Dimensional Single-Cell Analysis Identifies Organ-Specific Signatures and Conserved NK Cell Subsets in Humans and Mice. Immunity 2018, 49, 971-986.e5. [CrossRef] [PubMed]

42. Muntasell, A.; Vilches, C.; Angulo, A.; López-Botet, M. Adaptive reconfiguration of the human NK-cell compartment in response to cytomegalovirus: A different perspective of the host-pathogen interaction. Eur. J. Immunol. 2013, 43, 1133-1141. [CrossRef] [PubMed]

43. Gumaá, M.; Budt, M.; SaáezA, A.; Brckalo, T.; Hengel, H.; Angulo, A.; Loópez-Botet, M. Expansion of CD94/NKG2C+ NK cells in response to human cytomegalovirus-infected fibroblasts. Blood 2006, 107, 3624-3631. [CrossRef]

44. Gumaá, M.; Angulo, A.; Vilches, C.; Goómez-Lozano, N.; Malats, N.; Loópez-Botet, M. Imprint of human cytomegalovirus infection on the NK cell receptor repertoire. Blood 2004, 104, 3664-3671. [CrossRef] [PubMed]

45. Foley, B.; Cooley, S.; Verneris, M.R.; Pitt, M.; Curtsinger, J.; Luo, X.; Lopez-Vergès, S.; Lanier, L.L.; Weisdorf, D.; Miller, J.S. Cytomegalovirus reactivation after allogeneic transplantation promotes a lasting increase in educated NKG2C+natural killer cells with potent function. Blood 2012, 119, 2665-2674. [CrossRef]

46. O'Sullivan, T.E.; Sun, J.C.; Lanier, L.L. Natural Killer Cell Memory. Immunity 2015, 43, 634-645. [CrossRef]

47. Campos, C.; Pera, A.; Sanchez-Correa, B.; Alonso, C.; Lopez-Fernandez, I.; Morgado, S.; Tarazona, R.; Solana, R. Effect of age and CMV on NK cell subpopulations. Exp. Gerontol. 2014, 54, 130-137. [CrossRef]

48. Zhang, T.; Scott, J.M.; Hwang, I.; Kim, S. Cutting Edge: Antibody-Dependent Memory-like NK Cells Distinguished by FcR $\gamma$ Deficiency. J. Immunol. 2013, 190, 1402-1406. [CrossRef]

49. Muntasell, A.; Pupuleku, A.; Cisneros, E.; Vera, A.; Moraru, M.; Vilches, C.; López-Botet, M. Relationship of NKG2C Copy Number with the Distribution of Distinct Cytomegalovirus-Induced Adaptive NK Cell Subsets. J. Immunol. 2016, 196, 3818-3827. [CrossRef]

50. Elugli, E.; Emarcenaro, E.; Emavilio, D. NK Cell Subset Redistribution during the Course of Viral Infections. Front. Immunol. 2014, 5, 390. [CrossRef]

51. Hu, P.F.; Hultin, L.E.; Hultin, P.; Hausner, M.A.; Hirji, K.; Jewett, A.; Bonavida, B.; Detels, R.; Giorgi, J. V Natural killer cell immunodeficiency in HIV disease is manifest by profoundly decreased numbers of CD16+CD56+ cells and expansion of a population of CD16dimCD56- cells with low lytic activity. J. Acquir. Immune Defic. Syndr. Hum. Retrovirol. 1995, 10, 331-340. [CrossRef]

52. Björkström, N.K.; Ljunggren, H.-G.; Sandberg, J.K. CD56 negative NK cells: Origin, function, and role in chronic viral disease. Trends Immunol. 2010, 31, 401-406. [CrossRef]

53. Voigt, J.; Malone, D.F.G.; Dias, J.; Leeansyah, E.; Björkström, N.K.; Ljunggren, H.-G.; Gröbe, L.; Klawonn, F.; Heyner, M.; Sandberg, J.K.; et al. Proteome analysis of human CD56neg NK cells reveals a homogeneous phenotype surprisingly similar to CD56dim NK cells. Eur. J. Immunol. 2018, 48, 1456-1469. [CrossRef] [PubMed]

54. Eller, M.A.; Eller, L.A.; Ouma, B.J.; Thelian, D.; Gonzalez, V.D.; Guwatudde, D.; McCutchan, F.E.; Marovich, M.A.; Michael, N.L.; de Souza, M.S.; et al. Elevated Natural Killer Cell Activity Despite Altered Functional and Phenotypic Profile in Ugandans With HIV-1 Clade A or Clade D Infection. JAIDS J. Acquir. Immune Defic. Syndr. 2009, 51, 380-389. [CrossRef] [PubMed]

55. Orrantia, A.; Terrén, I.; Izquierdo-Lafuente, A.; Alonso-Cabrera, J.A.; Sandá, V.; Vitallé, J.; Moreno, S.; Tasias, M.; Uranga, A.; González, C.; et al. A NKp80-Based Identification Strategy Reveals that CD56neg NK Cells Are Not Completely Dysfunctional in Health and Disease. iScience 2020, 23, 101298. [CrossRef] [PubMed] 
56. Mavilio, D.; Lombardo, G.; Benjamin, J.; Kim, D.; Follman, D.; Marcenaro, E.; O’Shea, M.A.; Kinter, A.; Kovacs, C.; Moretta, A.; et al. Characterization of CD56-/CD16+ natural killer (NK) cells: A highly dysfunctional NK subset expanded in HIV-infected viremic individuals. Proc. Natl. Acad. Sci. USA 2005, 102, 2886-2891. [CrossRef]

57. Orrantia, A.; Terrén, I.; Vitallé, J.; Astarloa-Pando, G.; Zenarruzabeitia, O.; Borrego, F. Identification and Functional Analysis of Human CD56neg NK Cells by Flow Cytometry. STAR Protoc. 2020, 1, 100149. [CrossRef]

58. Solana, R.; Campos, C.; Pera, A.; Tarazona, R. Shaping of NK cell subsets by aging. Curr. Opin. Immunol. 2014, 29, 56-61. [CrossRef] [PubMed]

59. Mahapatra, S.; Mace, E.M.; Minard, C.G.; Forbes, L.R.; Vargas-Hernandez, A.; Duryea, T.K.; Makedonas, G.; Banerjee, P.P.; Shearer, W.T.; Orange, J.S. High-resolution phenotyping identifies NK cell subsets that distinguish healthy children from adults. PLoS ONE 2017, 12, e0181134. [CrossRef] [PubMed]

60. Stannard, K.A.; Lemoine, S.; Waterhouse, N.J.; Vari, F.; Chatenoud, L.; Gandhi, M.K.; Martinet, L.; Smyth, M.J.; Guillerey, C. Human peripheral blood DNAM-1neg NK cells are a terminally differentiated subset with limited effector functions. Blood Adv. 2019, 3, 1681-1694. [CrossRef]

61. Li, L.; Chen, H.; Marin, D.; Xi, Y.; Miao, Q.; Lv, J.; Banerjee, P.P.; Shaim, H.; Daher, M.; Basar, R.; et al. A novel immature natural killer cell subpopulation predicts relapse after cord blood transplantation. Blood Adv. 2019, 3, 4117-4130. [CrossRef]

62. Pegram, H.J.; Andrews, D.M.; Smyth, M.J.; Darcy, P.K.; Kershaw, M.H. Activating and inhibitory receptors of natural killer cells. Immunol. Cell Biol. 2011, 89, 216-224. [CrossRef] [PubMed]

63. Pende, D.; Falco, M.; Vitale, M.; Cantoni, C.; Vitale, C.; Munari, E.; Bertaina, A.; Moretta, F.; Del Zotto, G.; Pietra, G.; et al. Killer Ig-Like Receptors (KIRs): Their Role in NK Cell Modulation and Developments Leading to Their Clinical Exploitation. Front. Immunol. 2019, 10, 1179. [CrossRef] [PubMed]

64. Borrego, F.; Masilamani, M.; Kabat, J.; Sanni, T.B.; Coligan, J.E. The cell biology of the human natural killer cell CD94/NKG2A inhibitory receptor. Mol. Immunol. 2005, 42, 485-488. [CrossRef] [PubMed]

65. Ljunggren, H.-G.; Kärre, K. In search of the 'missing self': MHC molecules and NK cell recognition. Immunol. Today 1990, 11, 237-244. [CrossRef]

66. Ruggeri, L.; Capanni, M.; Urbani, E.; Perruccio, K.; Shlomchik, W.D.; Tosti, A.; Posati, S.; Rogaia, D.; Frassoni, F.; Aversa, F.; et al. Effectiveness of Donor Natural Killer Cell Alloreactivity in Mismatched Hematopoietic Transplants. Science 2002, 295, 2097-2100. [CrossRef]

67. Malmberg, K.-J.; Schaffer, M.; Ringdén, O.; Remberger, M.; Ljunggren, H.-G. KIR-ligand mismatch in allogeneic hematopoietic stem cell transplantation. Mol. Immunol. 2005, 42, 531-534. [CrossRef] [PubMed]

68. Ruggeri, L.; Capanni, M.; Casucci, M.; Volpi, I.; Tosti, A.; Perruccio, K.; Urbani, E.; Negrin, R.S.; Martelli, M.F.; Velardi, A. Role of Natural Killer Cell Alloreactivity in HLA-Mismatched Hematopoietic Stem Cell Transplantation. Blood 1999, 94, 333-339. [CrossRef]

69. He, Y.; Tian, Z. NK cell education via nonclassical MHC and non-MHC ligands. Cell. Mol. Immunol. 2017, 14, 321-330. [CrossRef]

70. Di Vito, C.; Mikulak, J.; Zaghi, E.; Pesce, S.; Marcenaro, E.; Mavilio, D. NK cells to cure cancer. Semin. Immunol. 2019, 41, 101272. [CrossRef]

71. Vitallé, J.; Terrén, I.; Orrantia, A.; Pérez-Garay, R.; Vidal, F.; Iribarren, J.A.; Rodríguez, C.; Lirola, A.M.L.; Bernal, E.; Zenarruzabeitia, O.; et al. CD300a inhibits CD16-mediated NK cell effector functions in HIV-1-infected patients. Cell. Mol. Immunol. 2019, 16, 940-942. [CrossRef]

72. Morvan, M.G.; Lanier, L.L. NK cells and cancer: You can teach innate cells new tricks. Nat. Rev. Cancer 2016, 16, 7-19. [CrossRef]

73. Bottino, C.; Biassoni, R.; Millo, R.; Moretta, L.; Moretta, A. The human natural cytotoxicity receptors (NCR) that induce HLA class I-independent NK cell triggering. Hum. Immunol. 2000, 61, 1-6. [CrossRef]

74. Barrow, A.D.; Martin, C.J.; Colonna, M. The Natural Cytotoxicity Receptors in Health and Disease. Front. Immunol. 2019, 10, 909. [CrossRef]

75. Waldhauer, I.; Steinle, A. NK cells and cancer immunosurveillance. Oncogene 2008, 27, 5932-5943. [CrossRef]

76. Vivier, E.; Ugolini, S.; Blaise, D.; Chabannon, C.; Brossay, L. Targeting natural killer cells and natural killer T cells in cancer. Nat. Rev. Immunol. 2012, 12, 239-252. [CrossRef] [PubMed]

77. Huntington, N.D.; Legrand, N.; Alves, N.L.; Jaron, B.; Weijer, K.; Plet, A.; Corcuff, E.; Mortier, E.; Jacques, Y.; Spits, H.; et al. IL-15 trans-presentation promotes human NK cell development and differentiation in vivo. J. Exp. Med. 2009, 206, 25-34. [CrossRef]

78. Becknell, B.; Caligiuri, M.A. Interleukin-2, Interleukin-15, and Their Roles in Human Natural Killer Cells. Adv. Immunol. 2005, 86, 209-239. [CrossRef]

79. Zwirner, N.W.; Domaica, C.I. Cytokine regulation of natural killer cell effector functions. BioFactors 2010, 36, 274-288. [CrossRef] [PubMed]

80. Eissens, D.N.; Spanholtz, J.; van der Meer, A.; van Cranenbroek, B.; Dolstra, H.; Kwekkeboom, J.; Preijers, F.W.M.B.; Joosten, I. Defining Early Human NK Cell Developmental Stages in Primary and Secondary Lymphoid Tissues. PLoS ONE 2012, 7, e30930. [CrossRef] [PubMed]

81. Di Vito, C.; Mikulak, J.; Mavilio, D. On the Way to Become a Natural Killer Cell. Front. Immunol. 2019, 10, 1812. [CrossRef]

82. Cichocki, F.; Sitnicka, E.; Bryceson, Y.T. NK cell development and function-Plasticity and redundancy unleashed. Semin. Immunol. 2014, 26, 114-126. [CrossRef] [PubMed] 
83. Adolfsson, J.; Månsson, R.; Buza-Vidas, N.; Hultquist, A.; Liuba, K.; Jensen, C.T.; Bryder, D.; Yang, L.; Borge, O.-J.; Thoren, L.A.M.; et al. Identification of Flt3+ Lympho-Myeloid Stem Cells Lacking Erythro-Megakaryocytic Potential. Cell 2005, 121, 295-306. [CrossRef] [PubMed]

84. Cichocki, F.; Grzywacz, B.; Miller, J.S. Human NK Cell Development: One Road or Many? Front. Immunol. 2019, 10, 2078. [CrossRef] [PubMed]

85. Miller, J.S.; McCullar, V.; Punzel, M.; Lemischka, I.R.; Moore, K.A. Single adult human CD34(+)/Lin-/CD38(-) progenitors give rise to natural killer cells, B-lineage cells, dendritic cells, and myeloid cells. Blood 1999, 93, 96-106. [CrossRef]

86. Miller, J.S.; Alley, K.A.; McGlave, P. Differentiation of natural killer (NK) cells from human primitive marrow progenitors in a stroma-based long-term culture system: Identification of a CD34+7+ NK progenitor. Blood 1994, 83, 2594-2601. [CrossRef] [PubMed]

87. Hao, Q.-L.; Zhu, J.; Price, M.A.; Payne, K.J.; Barsky, L.W.; Crooks, G.M.; Matsuo, K.; Suzuki, R.; Hamajima, N.; Ogura, M.; et al. Identification of a novel, human multilymphoid progenitor in cord blood. Blood 2001, 97, 3683-3690. [CrossRef] [PubMed]

88. Galy, A.; Travis, M.; Cen, D.; Chen, B. Human T, B, natural killer, and dendritic cells arise from a common bone marrow progenitor cell subset. Immunity 1995, 3, 459-473. [CrossRef]

89. Chen, L.; Youssef, Y.; Robinson, C.; Ernst, G.F.; Carson, M.Y.; Young, K.A.; Scoville, S.D.; Zhang, X.; Harris, R.; Sekhri, P.; et al. CD56 Expression Marks Human Group 2 Innate Lymphoid Cell Divergence from a Shared NK Cell and Group 3 Innate Lymphoid Cell Developmental Pathway. Immunity 2018, 49, 464-476.e4. [CrossRef] [PubMed]

90. Renoux, V.M.; Zriwil, A.; Peitzsch, C.; Michaëlsson, J.; Friberg, D.; Soneji, S.; Sitnicka, E. Identification of a Human Natural Killer Cell Lineage-Restricted Progenitor in Fetal and Adult Tissues. Immunity 2015, 43, 394-407. [CrossRef]

91. Freud, A.G.; Yokohama, A.; Becknell, B.; Lee, M.T.; Mao, H.C.; Ferketich, A.K.; Caligiuri, M.A. Evidence for discrete stages of human natural killer cell differentiation in vivo. J. Exp. Med. 2006, 203, 1033-1043. [CrossRef]

92. Freud, A.G.; Caligiuri, M.A. Human natural killer cell development. Immunol. Rev. 2006, 214, 56-72. [CrossRef]

93. Freud, A.G.; Yu, J.; Caligiuri, M.A. Human natural killer cell development in secondary lymphoid tissues. Semin. Immunol. 2014, 26, 132-137. [CrossRef]

94. Yu, J.; Freud, A.G.; Caligiuri, M.A. Location and cellular stages of natural killer cell development. Trends Immunol. 2013, 34, 573-582. [CrossRef] [PubMed]

95. Freud, A.G.; Keller, K.A.; Scoville, S.D.; Mundy-Bosse, B.L.; Cheng, S.; Youssef, Y.; Hughes, T.; Zhang, X.; Mo, X.; Porcu, P.; et al. NKp80 Defines a Critical Step during Human Natural Killer Cell Development. Cell Rep. 2016, 16, 379-391. [CrossRef] [PubMed]

96. Scoville, S.D.; Freud, A.G.; Caligiuri, M.A. Modeling Human Natural Killer Cell Development in the Era of Innate Lymphoid Cells. Front. Immunol. 2017, 8, 360. [CrossRef]

97. Scoville, S.D.; Mundy-Bosse, B.L.; Zhang, M.H.; Chen, L.; Zhang, X.; Keller, K.A.; Hughes, T.; Chen, L.; Cheng, S.; Bergin, S.M.; et al. A Progenitor Cell Expressing Transcription Factor ROR $\gamma$ t Generates All Human Innate Lymphoid Cell Subsets. Immunity 2016, 44, 1140-1150. [CrossRef]

98. Abel, A.M.; Yang, C.; Thakar, M.S.; Malarkannan, S. Natural Killer Cells: Development, Maturation, and Clinical Utilization. Front. Immunol. 2018, 9, 1869. [CrossRef] [PubMed]

99. Mace, E.M.; Hsu, A.P.; Monaco-Shawver, L.; Makedonas, G.; Rosen, J.B.; Dropulic, L.; Cohen, J.I.; Frenkel, E.P.; Bagwell, J.C.; Sullivan, J.L.; et al. Mutations in GATA2 cause human NK cell deficiency with specific loss of the CD56bright subset. Blood 2013, 121, 2669-2677. [CrossRef]

100. Romagnani, C.; Juelke, K.; Falco, M.; Morandi, B.; D’Agostino, A.; Costa, R.; Ratto, G.; Forte, G.; Carrega, P.; Lui, G.; et al. CD56brightCD16- Killer Ig-Like Receptor- NK Cells Display Longer Telomeres and Acquire Features of CD56dim NK Cells upon Activation. J. Immunol. 2007, 178, 4947-4955. [CrossRef] [PubMed]

101. Dulphy, N.; Haas, P.; Busson, M.; Belhadj, S.; De Latour, R.P.; Robin, M.; Carmagnat, M.; Loiseau, P.; Tamouza, R.; Scieux, C.; et al. An Unusual CD56brightCD16low NK Cell Subset Dominates the Early Posttransplant Period following HLA-Matched Hematopoietic Stem Cell Transplantation. J. Immunol. 2008, 181, 2227-2237. [CrossRef]

102. Collins, P.L.; Cella, M.; Porter, S.I.; Li, S.; Gurewitz, G.L.; Hong, H.S.; Johnson, R.P.; Oltz, E.M.; Colonna, M. Gene Regulatory Programs Conferring Phenotypic Identities to Human NK Cells. Cell 2019, 176, 348-360.e12. [CrossRef] [PubMed]

103. Lopez-Vergès, S.; Milush, J.M.; Pandey, S.; York, V.A.; Arakawa-Hoyt, J.; Pircher, H.; Norris, P.J.; Nixon, D.F.; Lanier, L.L. CD57 defines a functionally distinct population of mature NK cells in the human CD56dimCD16+ NK-cell subset. Blood 2010, 116, 3865-3874. [CrossRef] [PubMed]

104. Björkström, N.K.; Riese, P.; Heuts, F.; Andersson, S.; Fauriat, C.; Ivarsson, M.A.; Björklund, A.T.; Flodström-Tullberg, M.; Michaëlsson, J.; Rottenberg, M.E.; et al. Expression patterns of NKG2A, KIR, and CD57 define a process of CD56dim NK-cell differentiation uncoupled from NK-cell education. Blood 2010, 116, 3853-3864. [CrossRef] [PubMed]

105. Béziat, V.; Descours, B.; Parizot, C.; Debre, P.; Vieillard, V. NK Cell Terminal Differentiation: Correlated Stepwise Decrease of NKG2A and Acquisition of KIRs. PLoS ONE 2010, 5, e11966. [CrossRef] [PubMed]

106. Béziat, V.; Duffy, D.; Quoc, S.N.; Le Garff-Tavernier, M.; Decocq, J.; Combadière, B.; Debré, P.; Vieillard, V. CD56 bright CD16 + NK Cells: A Functional Intermediate Stage of NK Cell Differentiation. J. Immunol. 2011, 186, 6753-6761. [CrossRef]

107. Bozzano, F.; Della Chiesa, M.; Pelosi, A.; Antonini, F.; Ascierto, M.L.; Del Zotto, G.; Moretta, F.; Muccio, L.; Luganini, A.; Gribaudo, G.; et al. HCMV-controlling NKG2C+ NK cells originate from novel circulating inflammatory precursors. J. Allergy Clin. Immunol. 2021. [CrossRef] 
108. Copelan, E.A. Hematopoietic Stem-Cell Transplantation. N. Engl. J. Med. 2006, 354, 1813-1826. [CrossRef]

109. Bazinet, A.; Popradi, G. A General Practitioner's Guide to Hematopoietic Stem-cell Transplantation. Curr. Oncol. 2019, 26, 187-191. [CrossRef]

110. Niederwieser, D.; Baldomero, H.; Szer, J.; Gratwohl, M.; Aljurf, M.; Atsuta, Y.; Bouzas, L.F.; Confer, D.; Greinix, H.; Horowitz, M.; et al. Hematopoietic stem cell transplantation activity worldwide in 2012 and a SWOT analysis of the Worldwide Network for Blood and Marrow Transplantation Group including the global survey. Bone Marrow Transplant. 2016, 51 , 778-785. [CrossRef]

111. Passweg, J.R.; Baldomero, H.; Chabannon, C.; Basak, G.W.; Corbacioglu, S.; Duarte, R.; Dolstra, H.; Lankester, A.C.; Mohty, M.; Montoto, S.; et al. The EBMT activity survey on hematopoietic-cell transplantation and cellular therapy 2018: CAR-T's come into focus. Bone Marrow Transplant. 2020, 55, 1604-1613. [CrossRef]

112. Porrata, L.F. Autologous Graft-versus-Tumor Effect: Reality or Fiction? Adv. Hematol. 2016, 2016, 5385972. [CrossRef]

113. Porrata, L.; Ingle, J.; Litzow, M.; Geyer, S.; Markovic, S. Prolonged survival associated with early lymphocyte recovery after autologous hematopoietic stem cell transplantation for patients with metastatic breast cancer. Bone Marrow Transplant. 2001, 28 , 865-871. [CrossRef]

114. Porrata, L.F.; Gertz, M.A.; Inwards, D.J.; Litzow, M.R.; Lacy, M.Q.; Tefferi, A.; Gastineau, D.A.; Dispenzieri, A.; Ansell, S.M.; Micallef, I.N.M.; et al. Early lymphocyte recovery predicts superior survival after autologous hematopoietic stem cell transplantation in multiple myeloma or non-Hodgkin lymphoma. Blood 2001, 98, 579-585. [CrossRef] [PubMed]

115. Porrata, L.F.; Inwards, D.J.; Micallef, I.N.; Ansell, S.M.; Geyer, S.M.; Markovic, S.N. Early lymphocyte recovery post-autologous haematopoietic stem cell transplantation is associated with better survival in Hodgkin's disease. Br. J. Haematol. 2002, 117, 629-633. [CrossRef] [PubMed]

116. Porrata, L.; Litzow, M.; Tefferi, A.; Letendre, L.; Kumar, S.; Geyer, S.; Markovic, S. Early lymphocyte recovery is a predictive factor for prolonged survival after autologous hematopoietic stem cell transplantation for acute myelogenous leukemia. Leukemia 2002, 16, 1311-1318. [CrossRef] [PubMed]

117. Porrata, L.F.; Gastineau, D.A.; Padley, D.; Bundy, K.; Markovic, S.N. Re-infused Autologous Graft Natural Killer Cells Correlates with Absolute Lymphocyte Count Recovery after Autologous Stem Cell Transplantation. Leuk. Lymphoma 2003, 44, 997-1000. [CrossRef] [PubMed]

118. Rutella, S.; Rumi, C.; Laurenti, L.; Pierelli, L.; Sora', F.; Sica, S.; Leone, G. Immune reconstitution after transplantation of autologous peripheral CD34+ cells: Analysis of predictive factors and comparison with unselected progenitor transplants. Br. J. Haematol. 2000, 108, 105-115. [CrossRef]

119. Hiwase, D.K.; Hiwase, S.; Bailey, M.; Bollard, G.; Schwarer, A.P. Higher Infused Lymphocyte Dose Predicts Higher Lymphocyte Recovery, Which in Turn, Predicts Superior Overall Survival following Autologous Hematopoietic Stem Cell Transplantation for Multiple Myeloma. Biol. Blood Marrow Transplant. 2008, 14, 116-124. [CrossRef]

120. Porrata, L.F.; Litzow, M.R.; Inwards, D.J.; Gastineau, D.A.; Moore, S.B.; Pineda, A.A.; Bundy, K.L.; Padley, D.J.; Persky, D.; Ansell, S.M.; et al. Infused peripheral blood autograft absolute lymphocyte count correlates with day 15 absolute lymphocyte count and clinical outcome after autologous peripheral hematopoietic stem cell transplantation in non-Hodgkin's lymphoma. Bone Marrow Transplant. 2004, 33, 291-298. [CrossRef]

121. Porrata, L.F.; Inwards, D.J.; Ansell, S.M.; Micallef, I.N.; Johnston, P.B.; Gastineau, D.A.; Litzow, M.R.; Winters, J.L.; Markovic, S.N. Early Lymphocyte Recovery Predicts Superior Survival after Autologous Stem Cell Transplantation in Non-Hodgkin Lymphoma: A Prospective Study. Biol. Blood Marrow Transplant. 2008, 14, 807-816. [CrossRef]

122. Rueff, J.; Medinger, M.; Heim, D.; Passweg, J.; Stern, M. Lymphocyte Subset Recovery and Outcome after Autologous Hematopoietic Stem Cell Transplantation for Plasma Cell Myeloma. Biol. Blood Marrow Transplant. 2014, 20, 896-899. [CrossRef]

123. Porrata, L.F.; Inwards, D.J.; Micallef, I.N.; Johnston, P.B.; Ansell, S.M.; Hogan, W.J.; Markovic, S.N. Interleukin-15 Affects Patient Survival through Natural Killer Cell Recovery after Autologous Hematopoietic Stem Cell Transplantation for Non-Hodgkin Lymphomas. Clin. Dev. Immunol. 2010, 2010, 914945. [CrossRef]

124. Porrata, L.F.; Markovic, S.N. Timely reconstitution of immune competence affects clinical outcome following autologous stem cell transplantation. Clin. Exp. Med. 2004, 4, 78-85. [CrossRef]

125. Porrata, L.F.; Litzow, M.R.; Markovic, S.N. Immune Reconstitution After Autologous Hematopoietic Stem Cell Transplantation. Mayo Clin. Proc. 2001, 76, 407-412. [CrossRef]

126. Skerrett, D.; Rosina, O.; Bodian, C.; Isola, L.; Gudzowaty, O.; Scigliano, E.; Fruchtman, S. Human Leukocyte Antigens (HLA)-Cw as Prognostic Indicators in Autologous Transplantation for Lymphoma. Cancer Investig. 2001, 19, 487-494. [CrossRef]

127. Leung, W.; Handgretinger, R.; Iyengar, R.; Turner, V.; Holladay, M.S.; Hale, G.A. Inhibitory KIR-HLA receptor-ligand mismatch in autologous haematopoietic stem cell transplantation for solid tumour and lymphoma. Br. J. Cancer 2007, 97, 539-542. [CrossRef]

128. Venstrom, J.M.; Zheng, J.; Noor, N.; Danis, K.E.; Yeh, A.W.; Cheung, I.Y.; Dupont, B.; O’Reilly, R.J.; Cheung, N.-K.V.; Hsu, K.C. KIR and HLA Genotypes Are Associated with Disease Progression and Survival following Autologous Hematopoietic Stem Cell Transplantation for High-Risk Neuroblastoma. Clin. Cancer Res. 2009, 15, 7330-7334. [CrossRef]

129. Marra, J.; Greene, J.; Hwang, J.; Du, J.; Damon, L.; Martin, T.; Venstrom, J.M. KIR and HLA Genotypes Predictive of Low-Affinity Interactions Are Associated with Lower Relapse in Autologous Hematopoietic Cell Transplantation for Acute Myeloid Leukemia J. Immunol. 2015, 194, 4222-4230. [CrossRef] 
130. Gabriel, I.H.; Sergeant, R.; Szydlo, R.; Apperley, J.F.; Delavallade, H.; Alsuliman, A.; Khoder, A.; Marin, D.; Kanfer, E.; Cooper, N.; et al. Interaction between KIR3DS1 and HLA-Bw4 predicts for progression-free survival after autologous stem cell transplantation in patients with multiple myeloma. Blood 2010, 116, 2033-2039. [CrossRef]

131. Ali, M.; Oyama, Y.; Monreal, J.; Winter, J.; Tallman, M.; Gordon, L.; Williams, S.; Singhal, S.; Mehta, J. Reassessing the definition of myeloid engraftment after autotransplantation: It is not necessary to see $0.5 \times 109 / 1$ neutrophils on 3 consecutive days to define myeloid recovery. Bone Marrow Transplant. 2002, 30, 749-752. [CrossRef] [PubMed]

132. Storek, J.; Geddes, M.; Khan, F.; Huard, B.; Helg, C.; Chalandon, Y.; Passweg, J.; Roosnek, E. Reconstitution of the immune system after hematopoietic stem cell transplantation in humans. Semin. Immunopathol. 2008, 30, 425-437. [CrossRef] [PubMed]

133. Foley, B.; Felices, M.; Cichocki, F.; Cooley, S.; Verneris, M.R.; Miller, J.S. The biology of NK cells and their receptors affects clinical outcomes after hematopoietic cell transplantation (HCT). Immunol. Rev. 2014, 258, 45-63. [CrossRef]

134. Ruggeri, L.; Aversa, F.; Martelli, M.F.; Velardi, A. Allogeneic hematopoietic transplantation and natural killer cell recognition of missing self. Immunol. Rev. 2006, 214, 202-218. [CrossRef]

135. Yu, J.; Venstrom, J.M.; Liu, X.-R.; Pring, J.; Hasan, R.S.; O’Reilly, R.J.; Hsu, K.C. Breaking tolerance to self, circulating natural killer cells expressing inhibitory KIR for non-self HLA exhibit effector function after T cell-depleted allogeneic hematopoietic cell transplantation. Blood 2009, 113, 3875-3884. [CrossRef]

136. Sun, J.C.; Lanier, L.L. Tolerance of NK cells encountering their viral ligand during development. J. Exp. Med. 2008, 205, 1819-1828. [CrossRef]

137. Stern, M.; Paulussen, M.; Rischewski, J.; Tichelli, A.; Gratwohl, A. Missing ligand model in autologous stem cell transplantation. Br. J. Cancer 2008, 98, 852-853. [CrossRef]

138. Cella, M.; Longo, A.; Ferrara, G.B.; Strominger, J.L.; Colonna, M. NK3-specific natural killer cells are selectively inhibited by Bw4-positive HLA alleles with isoleucine 80. J. Exp. Med. 1994, 180, 1235-1242. [CrossRef]

139. López-Vázquez, A.; Rodrigo, L.; Martínez-Borra, J.; Pérez, R.; Rodríguez, M.; Fdez-Morera, J.L.; Fuentes, D.; Rodríguez-Rodero, S.; González, S.; López-Larrea, C. Protective Effect of the HLA-Bw4I80 Epitope and the Killer Cell Immunoglobulin-Like Receptor 3DS1 Gene against the Development of Hepatocellular Carcinoma in Patients with Hepatitis C Virus Infection. J. Infect. Dis. 2005, 192, 162-165. [CrossRef]

140. Arteche-López, A.; Kreutzman, A.; Alegre, A.; Sanz Martín, P.; Aguado, B.; González-Pardo, M.; Espiño, M.; Villar, L.M.; García Belmonte, D.; de la Cámara, R.; et al. Multiple myeloma patients in long-term complete response after autologous stem cell transplantation express a particular immune signature with potential prognostic implication. Bone Marrow Transplant. 2017, 52, 832-838. [CrossRef]

141. Bhutani, M.; Foureau, D.; Zhang, Q.; Robinson, M.; Wynn, A.S.; Steuerwald, N.M.; Druhan, L.J.; Guo, F.; Rigby, K.; Turner, M.; et al. Peripheral Immunotype Correlates with Minimal Residual Disease Status and Is Modulated by Immunomodulatory Drugs in Multiple Myeloma. Biol. Blood Marrow Transplant. 2019, 25, 459-465. [CrossRef] [PubMed]

142. Jacobs, B.; Tognarelli, S.; Poller, K.; Bader, P.; Mackensen, A.; Ullrich, E. NK Cell Subgroups, Phenotype, and Functions After Autologous Stem Cell Transplantation. Front. Immunol. 2015, 6, 583. [CrossRef]

143. Terszowski, G.; Passweg, J.R.; Stern, M. Natural killer cell immunity after transplantation. Swiss Med. Wkly. 2012, 142, w13700. [CrossRef] [PubMed]

144. Giebel, S.; Dziaczkowska, J.; Czerw, T.; Wojnar, J.; Krawczykkulis, M.; Nowak, I.; Holowiecka, A.; Segatti, A.; Kyrczkrzemien, S.; Kusnierczyk, P.; et al. Sequential recovery of NK cell receptor repertoire after allogeneic hematopoietic SCT. Bone Marrow Transplant. 2010, 45, 1022-1030. [CrossRef]

145. Vulpis, E.; Stabile, H.; Soriani, A.; Fionda, C.; Petrucci, M.; Mariggio', E.; Ricciardi, M.; Cippitelli, M.; Gismondi, A.; Santoni, A.; et al. Key Role of the CD56lowCD16low Natural Killer Cell Subset in the Recognition and Killing of Multiple Myeloma Cells. Cancers 2018, 10, 473. [CrossRef]

146. Peric, Z.; Wilson, J.; Durakovic, N.; Ostojic, A.; Desnica, L.; Vranjes, V.R.; Marekovic, I.; Serventi-Seiwerth, R.; Vrhovac, R. Early human cytomegalovirus reactivation is associated with lower incidence of relapse of myeloproliferative disorders after allogeneic hematopoietic stem cell transplantation. Bone Marrow Transplant. 2018, 53, 1450-1456. [CrossRef]

147. Yoon, J.-H.; Lee, S.; Kim, H.-J.; Jeon, Y.-W.; Lee, S.-E.; Cho, B.-S.; Lee, D.-G.; Eom, K.-S.; Kim, Y.-J.; Min, C.-K.; et al. Impact of cytomegalovirus reactivation on relapse and survival in patients with acute leukemia who received allogeneic hematopoietic stem cell transplantation in first remission. Oncotarget 2016, 7, 17230-17241. [CrossRef]

148. Green, M.L.; Leisenring, W.M.; Xie, H.; Walter, R.B.; Mielcarek, M.; Sandmaier, B.M.; Riddell, S.R.; Boeckh, M. CMV reactivation after allogeneic HCT and relapse risk: Evidence for early protection in acute myeloid leukemia. Blood 2013, 122, 1316-1324. [CrossRef]

149. Ito, S.; Pophali, P.; Wu, C.O.; Koklanaris, E.K.; Superata, J.; Fahle, G.A.; Childs, R.; Battiwalla, M.; Barrett, A.J. CMV reactivation is associated with a lower incidence of relapse after allo-SCT for CML. Bone Marrow Transplant. 2013, 48, 1313-1316. [CrossRef] [PubMed]

150. Muta, T.; Yoshihiro, T.; Jinnouchi, F.; Aoki, K.; Kochi, Y.; Shima, T.; Takenaka, K.; Ogawa, R.; Akashi, K.; Oshima, K. Expansion of NKG2C-expressing Natural Killer Cells after Umbilical Cord Blood Transplantation in a Patient with Peripheral T-cell Lymphoma with Cytotoxic Molecules. Intern. Med. 2018, 57, 861-866. [CrossRef] 
151. Elmaagacli, A.H.; Steckel, N.K.; Koldehoff, M.; Hegerfeldt, Y.; Trenschel, R.; Ditschkowski, M.; Christoph, S.; Gromke, T.; Kordelas, L.; Ottinger, H.D.; et al. Early human cytomegalovirus replication after transplantation is associated with a decreased relapse risk: Evidence for a putative virus-versus-leukemia effect in acute myeloid leukemia patients. Blood 2011, 118, 1402-1412. [CrossRef]

152. Cichocki, F.; Taras, E.; Chiuppesi, F.; Wagner, J.E.; Blazar, B.R.; Brunstein, C.; Luo, X.; Diamond, D.J.; Cooley, S.; Weisdorf, D.J.; et al. Adaptive NK cell reconstitution is associated with better clinical outcomes. JCI Insight 2019, 4, e125553. [CrossRef]

153. Cichocki, F.; Cooley, S.; Davis, Z.; DeFor, T.E.; Schlums, H.; Zhang, B.; Brunstein, C.G.; Blazar, B.R.; Wagner, J.; Diamond, D.J.; et al. CD56dimCD57+NKG2C + NK cell expansion is associated with reduced leukemia relapse after reduced intensity HCT. Leukemia 2016, 30, 456-463. [CrossRef]

154. Della Chiesa, M.; Falco, M.; Podestà, M.; Locatelli, F.; Moretta, L.; Frassoni, F.; Moretta, A. Phenotypic and functional heterogeneity of human NK cells developing after umbilical cord blood transplantation: A role for human cytomegalovirus? Blood 2012, 119, 399-410. [CrossRef]

155. Lu, X.; Kondo, Y.; Takamatsu, H.; Ohata, K.; Yamazaki, H.; Takami, A.; Akatsuka, Y.; Nakao, S. CD16+CD56-NK cells in the peripheral blood of cord blood transplant recipients: A unique subset of NK cells possibly associated with graft-versus-leukemia effect. Eur. J. Haematol. 2008, 81, 18-25. [CrossRef]

156. De Angelis, C.; Mancusi, A.; Ruggeri, L.; Capanni, M.; Urbani, E.; Velardi, A.; Stern, M. Expansion of CD56-Negative, CD16Positive, KIR-Expressing Natural Killer Cells after T Cell-Depleted Haploidentical Hematopoietic Stem Cell Transplantation. Acta Haematol. 2011, 126, 13-20. [CrossRef] [PubMed]

157. Kalwak, K.; Ussowicz, M.; Gorczyńska, E.; Turkiewicz, D.; Toporski, J.; Dobaczewski, G.; Latos-Grażyńska, E.; Ryczan, R.; Noworolska-Sauren, D.; Chybicka, A. Immunologic Effects of Intermediate-Dose IL-2 i.v. After Autologous Hematopoietic Cell Transplantation in Pediatric Solid Tumors. J. Interf. Cytokine Res. 2003, 23, 173-181. [CrossRef] [PubMed]

158. Porrata, L.; Inwards, D.; Lacy, M.; Markovic, S. Immunomodulation of early engrafted natural killer cells with interleukin-2 and interferon- $\alpha$ in autologous stem cell transplantation. Bone Marrow Transplant. 2001, 28, 673-680. [CrossRef] [PubMed]

159. Vlk, V.; Eckschlager, T.; Kavan, P.; Kabícková, E.; Koutecký, J.; Sobota, V.; Bubenik, J.; Pospísilová, D. Clinical ineffectiveness of IL-2 and/or IFN alpha administration after autologous PBSC transplantation in pediatric oncological patients. Pediatr. Hematol. Oncol. 2000, 17, 31-44. [CrossRef]

160. Burns, L.J.; Weisdorf, D.J.; DeFor, T.E.; Vesole, D.H.; Repka, T.L.; Blazar, B.R.; Burger, S.R.; Panoskaltsismortari, A.; Keevertaylor, C.A.; Zhang, M.-J.; et al. IL-2-based immunotherapy after autologous transplantation for lymphoma and breast cancer induces immune activation and cytokine release: A phase I/II trial. Bone Marrow Transplant. 2003, 32, 177-186. [CrossRef]

161. Shi, J.; Tricot, G.; Szmania, S.; Rosen, N.; Garg, T.K.; Malaviarachchi, P.A.; Moreno, A.; Dupont, B.; Hsu, K.C.; BaxterLowe, L.A.; et al. Infusion of haplo-identical killer immunoglobulin-like receptor ligand mismatched NK cells for relapsed myeloma in the setting of autologous stem cell transplantation. Br. J. Haematol. 2008, 143, 641-653. [CrossRef]

162. Shah, N.; Li, L.; Mccarty, J.; Kaur, I.; Yvon, E.; Shaim, H.; Muftuoglu, M.; Liu, E.; Orlowski, R.Z.; Cooper, L.; et al. Phase I study of cord blood-derived natural killer cells combined with autologous stem cell transplantation in multiple myeloma. Br. J. Haematol. 2017, 177, 457-466. [CrossRef]

163. Tschan-Plessl, A.; Kalberer, C.P.; Wieboldt, R.; Stern, M.; Siegler, U.; Wodnar-Filipowicz, A.; Gerull, S.; Halter, J.; Heim, D.; Tichelli, A.; et al. Cellular immunotherapy with multiple infusions of in vitro-expanded haploidentical natural killer cells after autologous transplantation for patients with plasma cell myeloma. Cytotherapy 2020, 23, 329-338. [CrossRef]

164. Nguyen, R.; Sahr, N.; Sykes, A.; McCarville, M.B.; Federico, S.M.; Sooter, A.; Cullins, D.; Rooney, B.; Janssen, W.E.; Talleur, A.C.; et al. Longitudinal NK cell kinetics and cytotoxicity in children with neuroblastoma enrolled in a clinical phase II trial. J. Immunother. Cancer 2020, 8, e000176. [CrossRef] [PubMed]

165. Klingemann, H.; Grodman, C.; Cutler, E.; Duque, M.; Kadidlo, D.; Klein, A.K.; Sprague, K.A.; Miller, K.B.; Comenzo, R.L.; Kewalramani, T.; et al. Autologous stem cell transplant recipients tolerate haploidentical related-donor natural killer cell-enriched infusions. Transfusion 2013, 53, 412-418. [CrossRef] [PubMed]

166. Van Elssen, C.H.M.J.; Ciurea, S.O. NK cell therapy after hematopoietic stem cell transplantation: Can we improve anti-tumor effect? Int. J. Hematol. 2018, 107, 151-156. [CrossRef] [PubMed] 